\title{
40. INTERPRETATION OF DEPOSITIONAL ENVIRONMENTS OF THE APTIAN/ALBIAN BLACK SHALES ON THE NORTH MARGIN OF THE BAY OF BISCAY (DSDP SITES 400 AND 402)
}

\author{
P.C. de Graciansky, ${ }^{1}$ G.A. Auffret, ${ }^{2}$ P. Dupeuble,${ }^{3}$ L. Montadert,${ }^{4}$ and C. Müller ${ }^{5}$
}

\begin{abstract}
During Leg 48, two closely spaced holes were drilled on the eastern Atlantic margin off Brittany. They offer the opportunity to compare the lithology and sedimentology of Lower Cretaceous black shales which have been deposited in different environments but in neighboring sites. Site 400 , in nearly 4500 meters of water, was already at a great depth in late Early Cretaceous times; in contrast, Site 402, now in more than 2000 meters of water, shows relatively shallow Aptian/Albian deposits.
\end{abstract}

\section{SEDIMENTOLOGICAL STUDY OF CORES 74 TO 62, HOLE 400A (UPPER APTIAN TO UPPER ALBIAN)}

\section{Introduction}

Hole 400A is the deepest hole of the three sites drilled on the northern continental margin of the Bay of Biscay. It was drilled in 4399 meters of water, at the foot of the Meriadzek escarpment in a half-graben between two tilted blocks (Figure 1). Lower Cretaceous rocks were encountered 654 meters below the sea floor and cored for 123.5 meters to the abandonment depth. The series comprises alternating beds of black shales and light colored calcareous mudstones and was divided, on board, into two sub-units:

Sub-unit 4A (Albian and upper Gargasian, Cores 62 to 67,654 to $711 \mathrm{~m}$ ) consists of marly chalk and carbonaceous siltstones and claystones, characterized by abundant syn-sedimentary deformation and slumping.

Sub-unit 4B (upper Gargasian, Cores 68 to 74,711 to $777.5 \mathrm{~m}$ ) consists of mud turbidite sequences with calcareous mudstones at their bottom and carbonaceous claystones at their top.

The boundary between these two units is transitional. The lower boundary of Sub-unit 4B corresponds to the bottom of the hole where the top of Sub-unit $4 \mathrm{~A}$ is the hiatus between Albian sediments and Maestrichtian calcareous chalks.

'Ecole Nationale Supérieure des Mines de Paris, 60, Bd. St Michel, 75272 Paris Cedex 06, France.

${ }^{2}$ Centre Océanologique de Bretagne, C.N.E.X.O., B.P. $337-29273$ Brest Cedex, France.

"Laboratoire de Géologie, Faculté des Sciences, Université de Rouen, 76130 Mont-Saint-Aignan, France.

${ }^{4}$ Institut Français du Pétrole, 1-4, avenue de Bois Préau, 92506 Rueil-Malmaison, France.

${ }^{5}$ Geologisch-Paläontologisches Institut der Universität Frankfürt am Main, Frankfürt am Main, Federal Republic of Germany. Present address: BEIC, Inst. Franç. du Petrole, B.P. 18, 92502 Rueil-Malmaison, France.

\section{Lithologies and Main Sedimentological Features}

\section{Sub-Unit 4B (Cores 68 to 74; $711.5 \mathrm{~m}$; Aptian)}

It consists of very fine grained sequences which comprise, from top to bottom, laminated silty claystones, carbonaceous claystones, and calcareous mudstone (Table 1 and Figure 2, Core 72, Section 3).

The sedimentological characteristics of these deposits suggest that calcareous mudstone and carbonaceous claystone were probably emplaced as mud turbidites in deep-sea basinal conditions. This is supported by features such as the constant range in thickness of each individual sequence (less than $1 \mathrm{~m}$ ), the relative constant thickness of individual lithologies within the sequences, the predominance of the clay-silt fraction on the sand fraction, the presence of only the upper part of Bouma's standard sequence (Td-e), and the importance of the bioturbation (Ricci-Lucchi, 1975).

The laminated silty claystones are probably the result of winnowing of the underlying carbonaceous claystones by bottom currents which concentrated the coarser grains and remixed components separated by turbidite processes.

Bioturbation is confined to the upper 20 to $30 \mathrm{~cm}$ of the calcareous mudstone and to the entire thickness of the carbonaceous claystone, i.e. to the upper part of the turbiditic sequence. Sequences thinner than 20 to $30 \mathrm{~cm}$ are bioturbated from bottom to top, but the thicker ones are bioturbated in their upper part only. It is well known, especially in flysch series, that bioturbation does not extend more than 30 to $40 \mathrm{~cm}$ below the sea floor. Because turbiditic floods are emplaced instantaneously compared to the long interval (several tens of thousands of years) that separates the emplacement of two successive flows, only the upper part of the most recently deposited layer is affected by bioturbation.

Organic carbon content within individual sequences is low and averages 0.5 per cent in Sub-unit 4B (Deroo et al., this volume). It is somewhat higher in the carbonaceous 


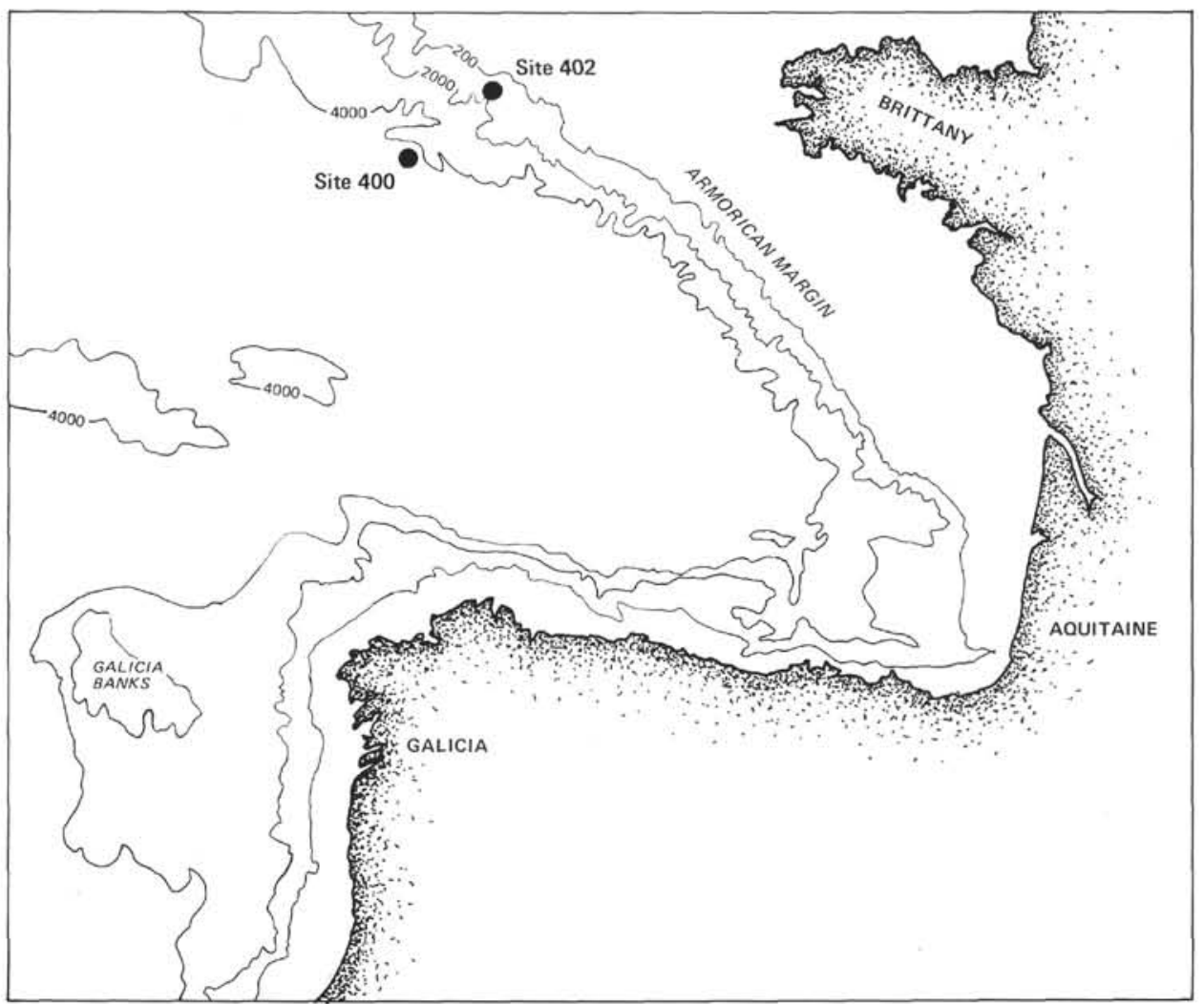

Figure 1. Sketch map showing location of Sites 400 and 402.

TABLE 1

Main Characteristics of the Various Types of Sediments in Hole 400A, Sub-Unit 4B (Aptian)

\begin{tabular}{l|l|l|l}
\hline Silty claystone & Dark medium gray (N4) & $\begin{array}{l}\text { Laminated and } \\
\text { more or less } \\
\text { burrowed }\end{array}$ & few $\mathrm{cm}$ \\
\hline Carbonaceous claystone & Black (N2) & Burrowed & 10 to $20 \mathrm{~cm}$ \\
\hline Calcareous mudstone & $\begin{array}{l}\text { Dark greenish gray (SG4/1) } \\
\text { Light greenish gray (5G6/1) } \\
\text { Grayish green (10G4/2) }\end{array}$ & $\begin{array}{l}\text { Burrowed } \\
\text { Not burrowed } \\
\text { Not burrowed }\end{array}$ & $\begin{array}{l}10 \\
\text { to } \\
100 \mathrm{~cm}\end{array}$ \\
\hline
\end{tabular}

claystones $(0.62 \%)$ than it is in the calcareous mudstone $(0.40 \%)$. This small difference is possibly insufficient to explain the difference in color of the two lithologies.

The mineral carbon content, on the contrary, changes from the base to the top of the sequence. Calcareous mudstones contain about 30 per cent $\mathrm{CaCO}_{3}$, but carbonaceous claystone only 5 per cent $\mathrm{CaCO}_{3}$.

In the calcareous mudstone, resistant and brittle calcareous nannofossils are abundant, but in the carbonaceous claystone, at the top of each sequence, brittle species show clear signs of dissolution. In the same way, calcareous foraminifers, especially planktonic species, are well represented, except in the carbonaceous claystones where they are nearly absent. Radiolarian and other siliceous tests occurring throughout are the only biogenic remains except for phosphatic (fish?) debris in the carbonaceous claystones.

The distinct correlation between low $\mathrm{CaCO}_{3}$ content and dissolution of calcareous micro- and nannofossils in the upper part of the turbidite sequence indicates that deposition took place close to the calcite compensation depth, as previously suggested for some alpine flyschs (Brouwer, 1965; Weidman, 1967; Kuenen, 1968; Hesse, 1975) and for other sediments of Cretaceous age from DSDP Hole 398D (de Graciansky and Chénet, in press). However, there may be another interpretation; there is also a clear correlation between relatively high organic matter contents and the dissolution state of coccoliths in the carbonaceous mudstones deposited in shallow depths at Site 402.

\section{Sub-Unit 4A (Cores 62 to 67,654 to $711 \mathrm{~m}$ )}

This sub-unit can be, in turn, divided into two parts, an upper one (4A part 1, Core 62 to Core 64 , Section 3; depth 654 to $677.5 \mathrm{~m}$; age, middle to upper Albian) and a lower one (4A part 2, Core 64, Section 4 to Core 67; depth 677.5 to $711 \mathrm{~m}$; lower and middle Albian to upper Gargasian).

Sub-unit 4A, part 2: The first syn-sedimentary deformation is seen in this part and especially in Core 66, Sections 2 and 3. Well-defined mud turbidite sequences (Figures 3,4,5), quite comparable to those of Sub-unit 2B, are present, with calcareous mudstones at the base, carbonate depleted, carbonaceous claystones in the middle, and laminated silty claystones at the top. From this part, the mineralogical composition has been determined by X-ray methods (Mélières, this volume) and a petrographical study has been made on several selected thin sections (Table 2).

Carbonaceous claystones are constituted mainly of smectite, illite, quartz (X-ray determination, Mélières, this volume); white micas, chlorites, tiny shards of quartz, and phosphate grains are visible under the microscope. Diagenetic clinoptilolite is volumetrically important and is 


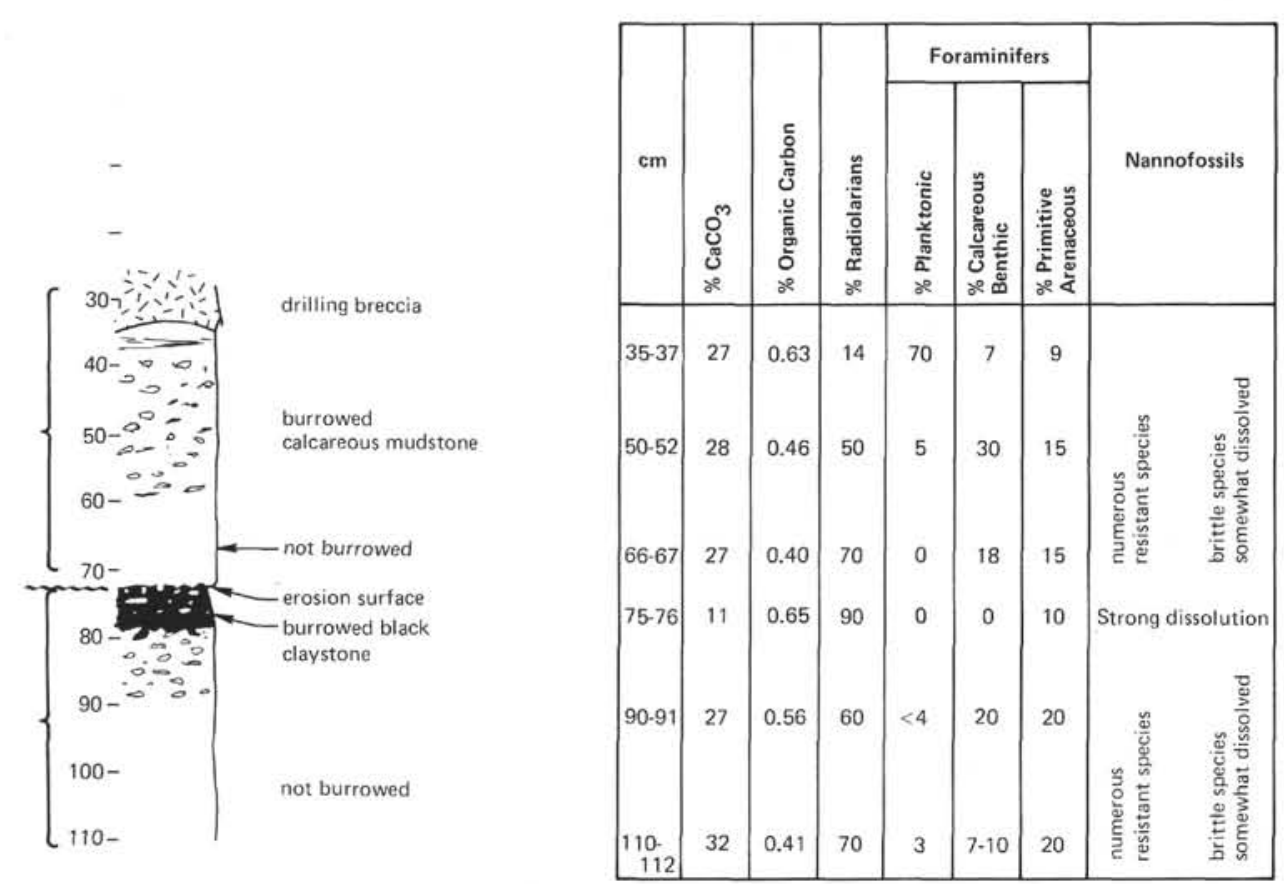

Figure 2. Data on two sequences, Hole 400A, Core 72, Section 3, 40-110 cm (Sub-unit $4 B$ ). Note absence of laminated silty claystone.

scattered within the matrix either as isolated crystals, or as clusters of single crystals, or as the result of the infilling of radiolarian shells that can be recognized easily under the microscope in smear slide (Mélières, this volume) as well as in thin sections (Plate 1, Figures 4, 5, 6). Replaced radiolarians, diatoms, and siliceous sponge spicules are the only marine biogenic remains; amorphous silica and opaline radiolarians, although rare, are not completely absent and are seen in thin sections.

Calcareous foraminifers are missing in the carbonaceous claystones (Table 2) and primitive arenaceous foraminifers are rare to very rare. Only the resistant species of calcareous nannoplankton are preserved and brittle species are corroded and broken. In correlation, mineral carbon content is low $\left(\mathrm{CaCO}_{3}\right.$ average value $6 \%$, Figures 6 and 7 ). Microscopic recognizable plant fragments are abundant (Plate 1), in agreement with the relatively high organic carbon content in these lithologies (average value $2.36 \%$ ) and with what is known about accumulation of plant debris in the upper part of graded sequences in flysch series (Bouma, 1965).

The matrix of the calcareous mudstone includes calcareous micrite and clay minerals (mainly smectite and illite). Microscopic observation shows rare mica flakes and quartz grains, with much rarer plant debris and radiolarians (pseudomorphozed by clinoptilolite) compared to the immediately overlying carbonaceous claystones. Organic carbon contents are low here, with an average value of only 0.35 per cent (Figure 5 ). Resistant as well as brittle species of calcareous nannofossils are abundant. There is a difference between calcareous mudstones of Sub-unit 4B and Sub-unit 4A, part 2; planktonic foraminifers are rare to absent in part 2 , with only a few benthic calcareous foraminifers present. The $\mathrm{CaCO}_{3}$ content varies in these lithologies from an average value of 30 per cent in Sub-unit
$4 \mathrm{~B}$, part 2, to 23 per cent in Sub-unit $4 \mathrm{~B}$, part 1 , to 60 or 70 per cent at the top of Sub-unit $4 \mathrm{~A}$ (Core 62). The lower carbonate content in Sub-unit 4A, part 2, may be correlated with the presence of several dark colored sequences (especially in Core 64, Section 5; Core 65, Section 1; and Core 66 , Section 4) and may be explained by a decreased calcareous pelagic sediment supply during the corresponding period, i.e. during early and middle Albian, as observed in the Paris Basin and in the outer Alpine domain (Vocontian Zone; Cotillon, 1971; Moulade, 1974).

In laminated silty claystones, the following components have been identified: inframicroscopic quartz, illite, smectite, abundant calcareous nannofossils, and radiolarian tests which are replaced by clinoptilolite and planktonic foraminifers. Various grains define the lamination, such as clusters of zeolite crystals, calcite (echinoderm?) pieces, vegetal debris, small elongated masses of clay minerals, or mica flakes (Table 2).

The abundance of vegetal debris and the organic carbon content (average 1\%) are intermediate between those of the carbonaceous claystone (average $\mathrm{C}$ organic content $2.36 \%$ ) and of calcareous mudstone (average $\mathrm{C}$ organic content $0.35 \%)$. This intermediate value may result from the reworking of turbiditic sediments by bottom currents which probably caused the emplacement of laminated silty claystones. A model of a mud turbidite sequence is shown in Figure 8.

Sub-unit 4A, part 1: This part is distinguished from the underlying one by some differences in lithology and by the presence of numerous syn-sedimentary slumping of unconsolidated and cemented sediments (Figures 6 and 9).

The carbonate-depleted claystones are absent and black calcareous silty mudstones and light colored calcareous mudstones are present, closely interfingered by the slumping. Syn-sedimentary deformation is shown by 
$65-2$

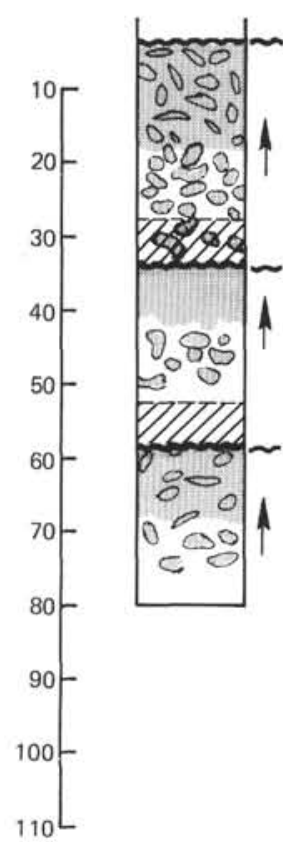

$66-4$

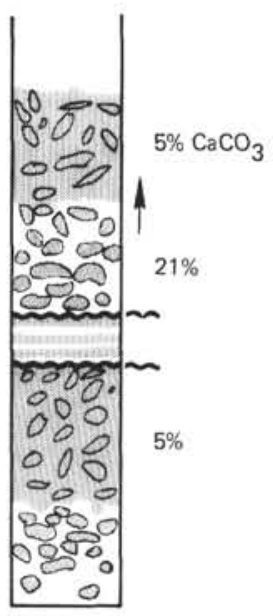

66-1



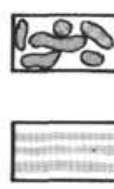


bioturbations

laminated silty claystone

carbonaceous claystone (N3)

(generally bioturbated)

calcareous mudstone $\{5 Y 5 / 2\}$

silty calcareous mudstone (5Y 4/2)

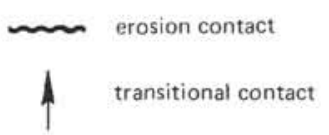

Figure 3. Some typical turbidite sequences of Hole 400A (Sub-unit 4A, part 2).

fragments of folded layers and by the succession of several different dipping in the bedding within a single core. One of these slumped sequences is illustrated in Figure 9 (Core 63, Section 4).

Light colored calcareous mudstones ( = marly chalk) are highly bioturbated and most of the burrows are elongated, bent, or folded by the slumping. Their microscopic and sub-microscopic components are not much different from those of the overlying part. However, a distinct difference consists in the presence, in this part, of relatively numerous planktonic foraminifers (globigerinids, Hedbergella, etc., Plate 1, Figures 7, 8, 9; Plate 2, Figure 1) the abundance of which increases from the base to the top of the series, i.e., from Core 64 to Core 62 . The infilling of the chambers of these foraminifers consists generally of calcimicrite and clays, or of clinoptilolite crystals (Plate 1, Figure 9; Plate 2, Figure 1), or pyrite. Benthic foraminifers are present but are never numerous. Reflecting the increasing abundance of the planktonic forms throughout the series, the $\mathrm{CaCO}_{3}$ content increases from 25 to 30 per cent in Core 64, Section 2 and 3 to 67 per cent in Core 62, Section 1 (Figures 6 and 7). However, the brittle species of calcareous nannofossils show strong signs of dissolution and are badly preserved, again suggesting that the depth of deposition was probably close to the CCD.

The slumped calcareous mudstones and the dark colored laminated mudstones which separate them comprise nearly the same components but, in the laminated dark mudstones (Plate 2, Figures $7,8,9$ ) the maximum grain size is somewhat coarser. Calcite monocrysts (echinoderms ?) and 


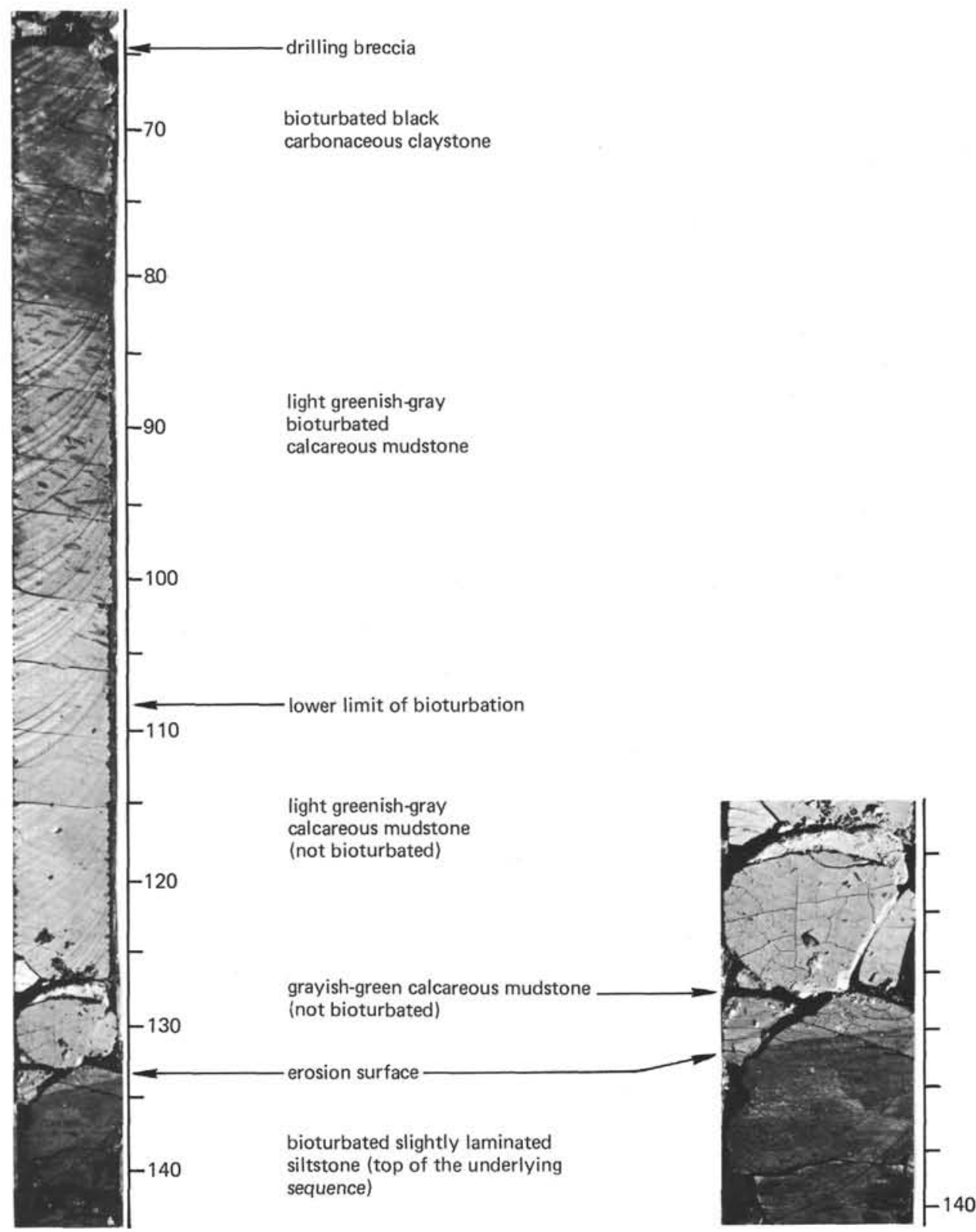

Figure 4. Typical mud turbidite sequence of Hole 400A, Core 66, Section 3 (Sub-unit $4 A$, part 2). (See Mélières, this volume).

reworked micritic intraclasts increase in the micritic matrix, whereas terrigenous quartz grains do not. Reflecting the darker color, plant debris is much more abundant and may be seen in thin section. The organic carbon content (Figure 9) is quite high (average 1.8\%) in Core 63, Sections 4 and 3 , but decreases upward in both lithologies (average $0.4 \%$ ).

\section{Variations of the Organic Carbon Contents}

The organic carbon content fluctuates within the Cretaceous stratigraphic column of Site 400 in two ways (Figures 6 and 7): (1) the content is dependent on the lithological type; the carbonate-depleted claystones which lie on top of the turbidite sequences are generally richer in organic matter than the underlying calcareous mudstones; (2) the content depends on the age of the sediment, i.e., on temporal variations of organic matter influx into the pelagic environment.

From Core 74 to Core 69 (upper Aptian) organic carbon contents are low and independent of lithology. A relatively high percentage in planktonic cellulosic forms compared to the terrestrial ones may be anticipated at these levels, following similar cases at Hole 398D (Habib, in press).

From Core 68 to Core 64, Section 4 (uppermost Aptian, lower and middle Albian) the organic carbon contents are high in carbonaceous claystones (maximum value $4.2 \%$ ), low in calcareous mudstones, and intermediate in laminated silty claystones, which results from reworking of the former sediment into the latter one. A few isolated low values are observed in Core 65 , but they may be insignificant because the sampling was poor in this core. 

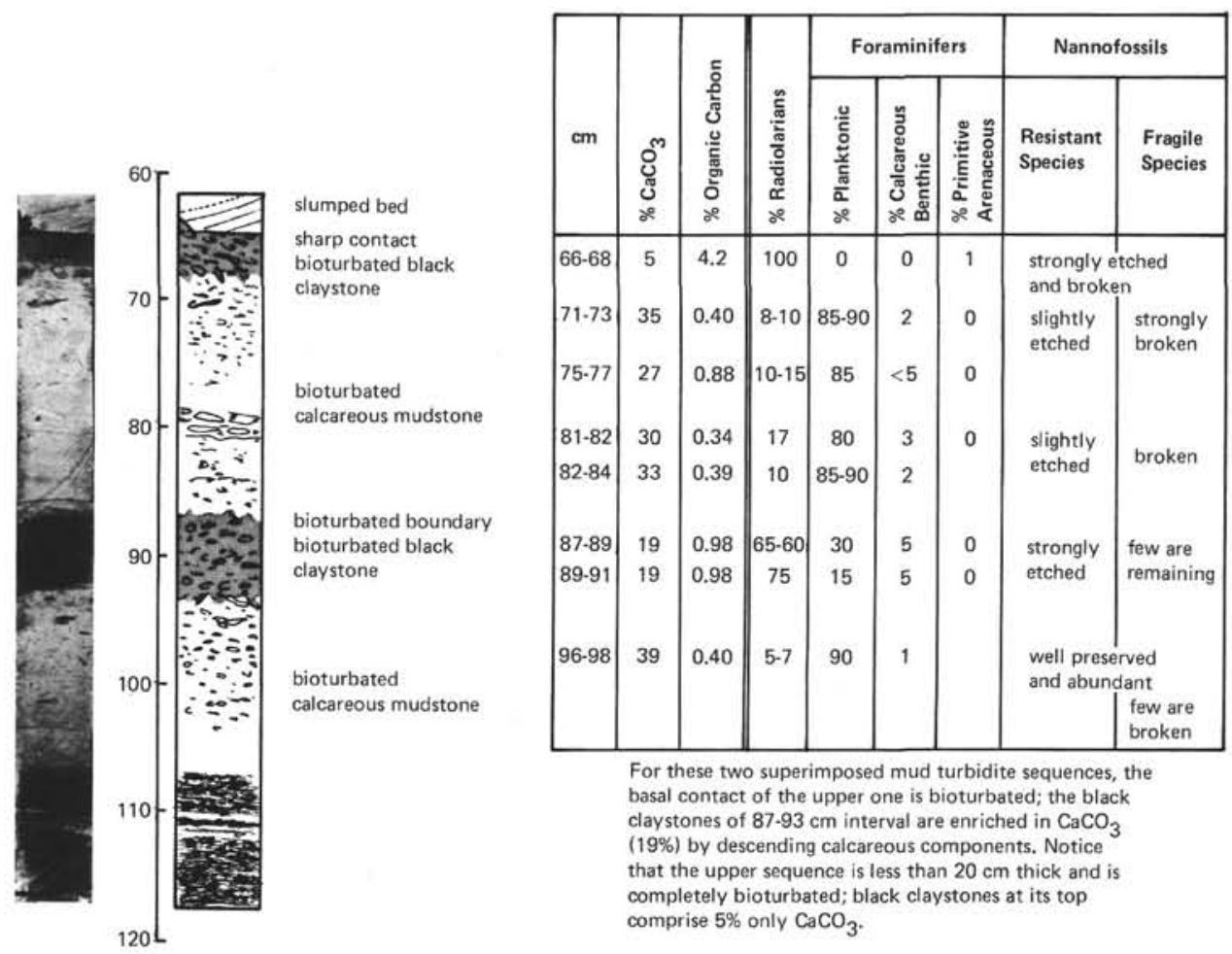

Figure 5. Two typical mud turbidite sequences of Hole 400A, Core 64, Section 4/Subunit $4 A$, part 2 ).

From Core 64 , Section 3 , to Core 62 , the original bedding has been disturbed both by strong burrowing and syn-sedimentary deformation; the organic carbon contents are relatively independent of the facies type.

From Core 64, Section 3, to Core 63 (middle to upper Albian) the percentage in organic $\mathrm{C}$ remains high, mostly between 2 and 3 per cent, but some values only reach 0.5 per cent. In Core 62 (uppermost Albian) low values are observed again (less than 1\%) in the various types of sediments.

Because the organic matter has been demonstrated to be of mainly terrestrial origin (Deroo et al., this volume), the variations in organic carbon content simply reflects the fluctuations in the influx of plant debris to the pelagic environment. From this point of view, three periods can be recognized: (1) late Aptian, low influx; (2) early and middle Albian, high influx and relative predominance of terrestrial influence; (3) late Albian, low influx of plant debris again and predominance of marine influences.

This sequence of events is comparable to those observed within approximately the same periods at Site 402 and at Hole 398D (Iberian outer margin).

\section{Variations of the Calcium Carbonate Contents}

The $\mathrm{CaCO}_{3}$ content like the organic carbon exhibits two scales of variations (Figures 6 and 7): within the sequence itself, i.e., at the metric scale, and at the scale of the geological stage or substage.
Special attention has been devoted to the upper, hemipelagic part of the sequences, which are the finest grained and which are supposed to have come under the influences of corrosive waters if deeper than the CCD.

Hemipelagites of Site 400 , Cores 74 to 64 , are poor in carbonate (less than 5\%). Calcareous foraminifers are absent and only calcareous nannofossils show signs of dissolution. These sediments were probably deposited close to the $\mathrm{CCD}$, at least below the lysocline of planktonic foraminifers. In the overlying sediments (Cores 63 and 62, upper Albian), hemipelagites cannot be distinguished easily from other lithologies because of strong burrowing and syn-sedimentary deformation. However, clear dissolution of calcareous nannofossils suggests that the depth of sedimentation was still near the CCD.

In contrast, the relatively high $\mathrm{CaCO}_{3}$ contents in the calcareous mudstones and the fairly good preservation state of calcareous foraminifers and nannofossils show that they have been protected from dissolution by rapid transportation and burial. It should be noted that aragonitic shells (ammonites or epistominids) are absent in the calcareous biogenic remains. This may be because the ecological conditions were not favorable to the development of organisms with an aragonitic shell, or the environmental conditions did not allow their preservation since the initial sedimentation depth of the calcareous muds prior to their redeposition was deeper than the ACD (Dupeuble, this volume). 
TABLE 2

Petrographical Study of Some Thin Sections Leg 48, Hole 400A, Lower Cretaceous

\begin{tabular}{|c|c|c|c|c|c|c|c|c|c|c|c|c|c|c|c|c|}
\hline & \multirow[b]{3}{*}{$\begin{array}{c}\text { Core } \\
\text { Section } \\
\text { Interval } \\
\end{array}$} & \multirow{2}{*}{\multicolumn{3}{|c|}{ Calcareous }} & \multirow[b]{3}{*}{ Foraminifers } & \multirow{2}{*}{\multicolumn{2}{|c|}{$\begin{array}{l}\text { Radiolarians } \\
\text { (from } 1-2 \% \\
\text { up to } 25-30 \% \text { ) }\end{array}$}} & \multirow{3}{*}{ 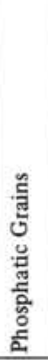 } & \multirow[b]{3}{*}{$\begin{array}{c}\text { Plant } \\
\text { Fragments }\end{array}$} & \multirow[b]{3}{*}{$\begin{array}{c}\text { Quartz } \\
\text { (generally } \\
<1 \% \text { ) }\end{array}$} & \multirow[b]{3}{*}{$\begin{array}{c}\text { Micas } \\
\text { (generally } \\
<1 \% \text { ) }\end{array}$} & \multicolumn{4}{|c|}{ Clinoptilolite } & \multirow[b]{3}{*}{ Other Features } \\
\hline & & & & & & & & & & & & \multirow{2}{*}{ 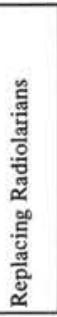 } & \multirow{2}{*}{ 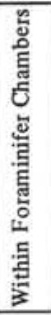 } & \multirow[b]{2}{*}{ 总 } & \multirow{2}{*}{ 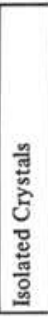 } & \\
\hline & & 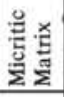 & 离 & 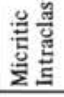 & & 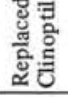 & 总 & & & & & & & & & \\
\hline 气̆ & $\begin{array}{l}62-1 \\
88-90\end{array}$ & $\mathrm{xx}$ & $\mathrm{x}$ & o & $\begin{array}{l}\text { plactonic } \\
\text { common }\end{array}$ & $\mathrm{x}$ & $\mathrm{x}$ & & $x x$ & $\begin{array}{l}\text { very small } \\
\text { grains }\end{array}$ & very rare & $\mathrm{x}$ & & & $\mathrm{x}$ & $\begin{array}{l}\text { Bioturbation, thin shells } \\
\text { of pelecypods, calcitized }\end{array}$ \\
\hline 尝 & $\begin{array}{l}62-5 \\
32-34\end{array}$ & $x x x$ & $\mathrm{x}$ & o & $\begin{array}{l}\text { planctonic } \\
\text { present }\end{array}$ & $x$ & & $x$ & $\mathrm{x}$ & rare & very rare & $\mathrm{xx}$ & & $\mathrm{x}$ & $x$ & \\
\hline 己ี & $\begin{array}{l}63-1 \\
65-68\end{array}$ & $\mathrm{xxx}$ & & o & $\begin{array}{l}\text { small } \\
\text { planctonic } \\
\text { forms }\end{array}$ & $\mathrm{xx}$ & $\mathrm{x}$ & $\mathrm{x}$ & $\mathrm{x}$ & $\begin{array}{l}\text { very small } \\
\text { and rare }\end{array}$ & very rare & $\mathrm{xx}$ & & & & $\begin{array}{l}\text { Bioturbation; pyrite } \\
\text { within foraminifer } \\
\text { chambers }\end{array}$ \\
\hline 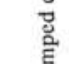 & $\begin{array}{l}64-1 \\
74-76\end{array}$ & $x x x$ & & o & $\begin{array}{l}\text { planctonic } \\
\text { present }\end{array}$ & $x x$ & & $\mathrm{x}$ & $\mathrm{x}$ & $\begin{array}{l}\text { very small } \\
\text { grains }\end{array}$ & $\begin{array}{l}\text { green biotite } \\
\text { white micas }\end{array}$ & $\mathrm{xx}$ & $\mathrm{x}$ & $\mathrm{x}$ & $\mathrm{x}$ & Bioturbation \\
\hline ฝี & $\begin{array}{l}64-3 \\
26-28\end{array}$ & $\mathrm{xxx}$ & $\mathrm{x}$ & o & & $\mathrm{xx}$ & $\mathrm{x}$ & $\mathrm{x}$ & $x x$ & $\begin{array}{l}\text { very little } \\
\text { grains }\end{array}$ & $\begin{array}{l}\text { rare white } \\
\text { micas }\end{array}$ & $\mathrm{xx}$ & & $\mathrm{x}$ & $\mathrm{x}$ & Glauconite \\
\hline \multirow{2}{*}{ 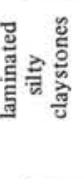 } & $\begin{array}{l}62-3 \\
7-10\end{array}$ & $x x x$ & $\mathrm{x}$ & $\mathrm{x}$ & $\begin{array}{l}\text { abundant } \\
\text { planctonic } \\
\text { forms }\end{array}$ & $x$ & & $\mathrm{x}$ & $x$ & $\begin{array}{l}\text { very small } \\
\text { grains }\end{array}$ & white micas & $x$ & & $\mathrm{x}$ & $\mathrm{x}$ & $\begin{array}{l}\text { Laminations; crinoids } \\
\text { grains }\end{array}$ \\
\hline & $\begin{array}{l}62-3 \\
83-85\end{array}$ & $\mathrm{xxx}$ & $\mathrm{x}$ & $\mathrm{x}$ & planctonic & $\mathrm{xx}$ & $\mathrm{x}$ & $\mathrm{x}$ & $\mathrm{xxx}$ & & rare & $\mathrm{xx}$ & & & & $\begin{array}{l}\text { Laminations; thin shells } \\
\text { of pelecypods or of } \\
\text { brachiopods }\end{array}$ \\
\hline \multirow{4}{*}{ 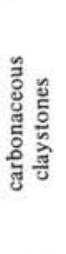 } & $\begin{array}{l}64-3 \\
96-97\end{array}$ & o & o & o & nil & $\mathrm{x}$ & & $\mathrm{x}$ & $\mathrm{xxxx}$ & $\begin{array}{l}\text { very small } \\
\text { shards }\end{array}$ & & $\mathrm{xx}$ & & $\mathrm{x}$ & $\mathrm{x}$ & \\
\hline & $\begin{array}{l}65-2 \\
96-97\end{array}$ & o & $\mathrm{x}$ & o & nil & $\mathrm{xxx}$ & & $\mathrm{x}$ & $\mathrm{xxxx}$ & & white micas & $\mathrm{xxx}$ & & & $\mathrm{x}$ & \\
\hline & $\begin{array}{l}66-2 \\
29-31\end{array}$ & o & o & o & nil & $x x x$ & & $x$ & $x \times x x$ & $\begin{array}{l}\text { very small } \\
\text { shards }\end{array}$ & white micas & $x x x$ & & $\mathrm{xx}$ & $\mathrm{xx}$ & \\
\hline & $\begin{array}{l}66-4 \\
54-56\end{array}$ & o & o & o & nil & $\mathrm{xxx}$ & & $\mathrm{x}$ & $\operatorname{xxxx}$ & small grains & white micas & $x x x$ & & & & \\
\hline \multirow{3}{*}{ 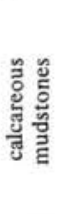 } & $\begin{array}{l}65-1 \\
96-99\end{array}$ & $x x x$ & $x$ & o & nil & $x x x$ & $\mathrm{x}$ & $\mathrm{x}$ & $\mathrm{xxx}$ & small grains & white micas & $x x x$ & & $x$ & $\mathrm{x}$ & Bioturbation \\
\hline & $\begin{array}{l}66-1, \\
99-100\end{array}$ & $\mathrm{xxx}$ & & o & nil & $\mathrm{x}$ & $\mathrm{xx}$ & $\mathrm{x}$ & $x \mathbf{x}$ & $\begin{array}{l}\text { small grains } \\
\text { common }\end{array}$ & $\begin{array}{l}\text { chlorite } \\
\text { white micas } \\
\text { common }\end{array}$ & $\mathrm{x}$ & & & & Siliceous sponge spicules \\
\hline & $\begin{array}{l}69, \\
\text { CC }\end{array}$ & $\mathrm{xxx}$ & $\mathrm{x}$ & o & $\begin{array}{l}\text { planctonic } \\
\text { present }\end{array}$ & $\mathrm{x}$ & $\mathrm{x}$ & $\mathrm{x}$ & $x x$ & $\begin{array}{l}\text { small grains } \\
\text { common }\end{array}$ & $\begin{array}{l}\text { white micas } \\
\text { common }\end{array}$ & $\mathrm{x}$ & & & & Urchin spine \\
\hline
\end{tabular}

The maximum $\mathrm{CaCO}_{3}$ content in the redeposited calcareous mudstones fluctuates all along the stratigraphical column; from Core 74 to Core 68 it averages 30 per cent, values ranging between 19 and 49 per cent; from Core 67 to Core 64 the average is 23 per cent, with extremes of 19 and 27 per cent; from Core 64 and upwards it increases to 67 per cent in Core 62.

Variations in the $\mathrm{CaCO}_{3}$ percentage (Figure 7) in some sequences, especially within the upper Albian ones, reflect the relative proportions of planktonic foraminifers per unit of volume of the redeposited sediments, as exemplified in Core 64, Section 4 (Figure 5). In other sequences of the upper Aptian, but less frequently, high $\mathrm{CaCO}_{3}$ percentages are linked to abundant calcareous benthic foraminifers (noticeably Core 69, Section 1, $90 \mathrm{~cm}$; Core 65, Section 1, $140 \mathrm{~cm})$.

It can be shown on a diagram of $\mathrm{CaCO}_{3}$ versus organic $\mathrm{C}$ percentages (Figure 10) that the fluctuations of organic and mineral carbon are roughly opposite. This is clear within a single sequence. In the upper Albian, mineral carbon contents are high and planktonic foraminifers are numerous, but organic carbon contents are low. In contrast, in the lower and middle Albian, $\mathrm{CaCO}_{3}$ percentages are lowest, calcareous foraminifers are rare, but organic carbon contents and plant debris are abundant. Quartz grains and mica flakes, although rare and small sized, are relatively numerous in thin-section. Although the dominance of marine influences is shown, for example, by the abundance of the nannofossils, fluctuations in the terrigenous influx are recorded in the sediments.

\section{Evolution of the Environmental Conditions During the Black Shale Episode of Site $\mathbf{4 0 0}$}

During late Aptian (Gargasian) and early Albian time, mud turbiditic flows were deposited in deep-sea basinal conditions on a flat relief. During middle and late Albian 


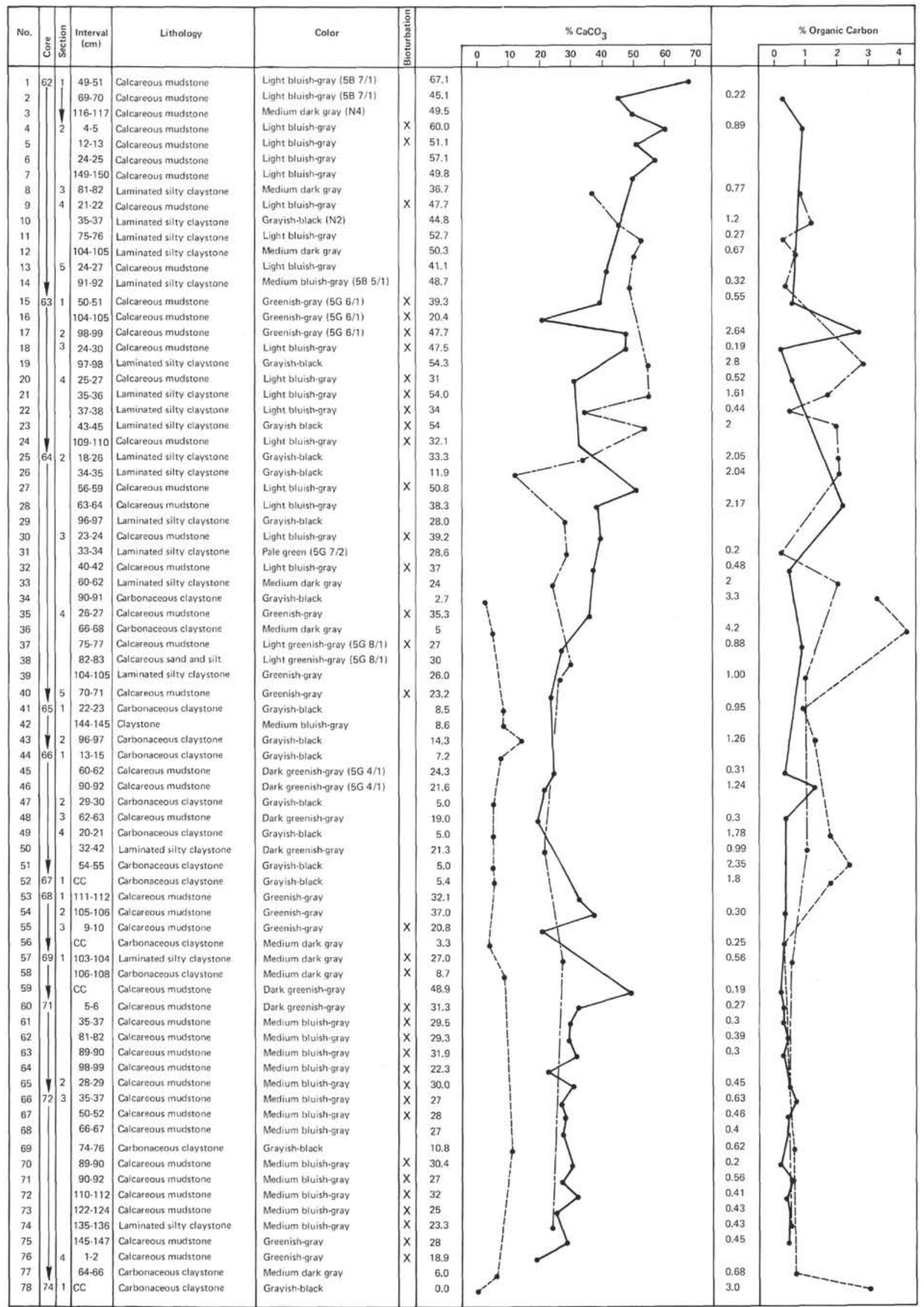

Figure 6. Organic carbon and $\mathrm{CaCO}_{3}$ contents relative to various lithological types (Hole 400A). 


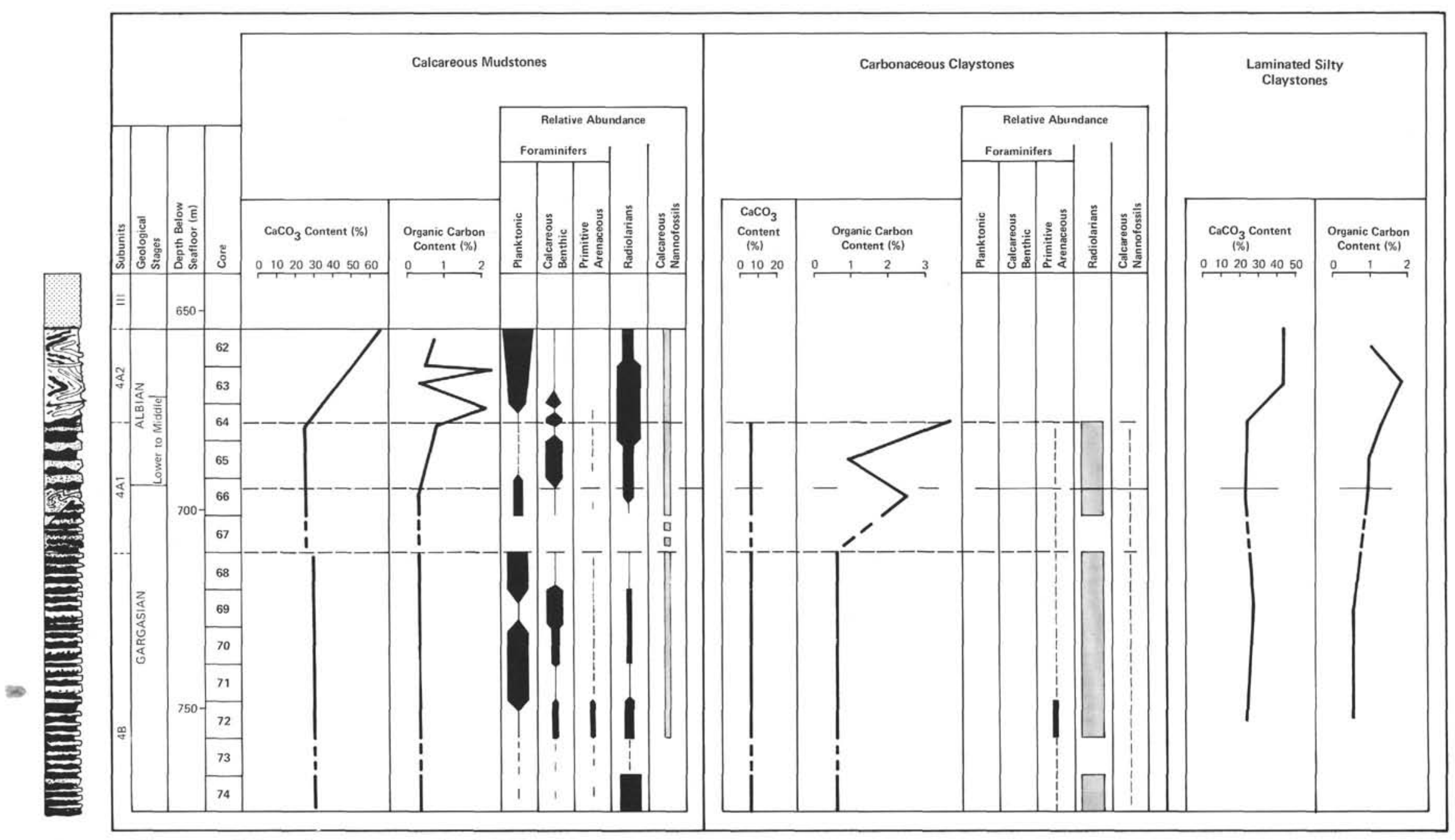

Figure 7. Variation of the main components in the different types of sediments of Hole $400 \mathrm{~A}$. 


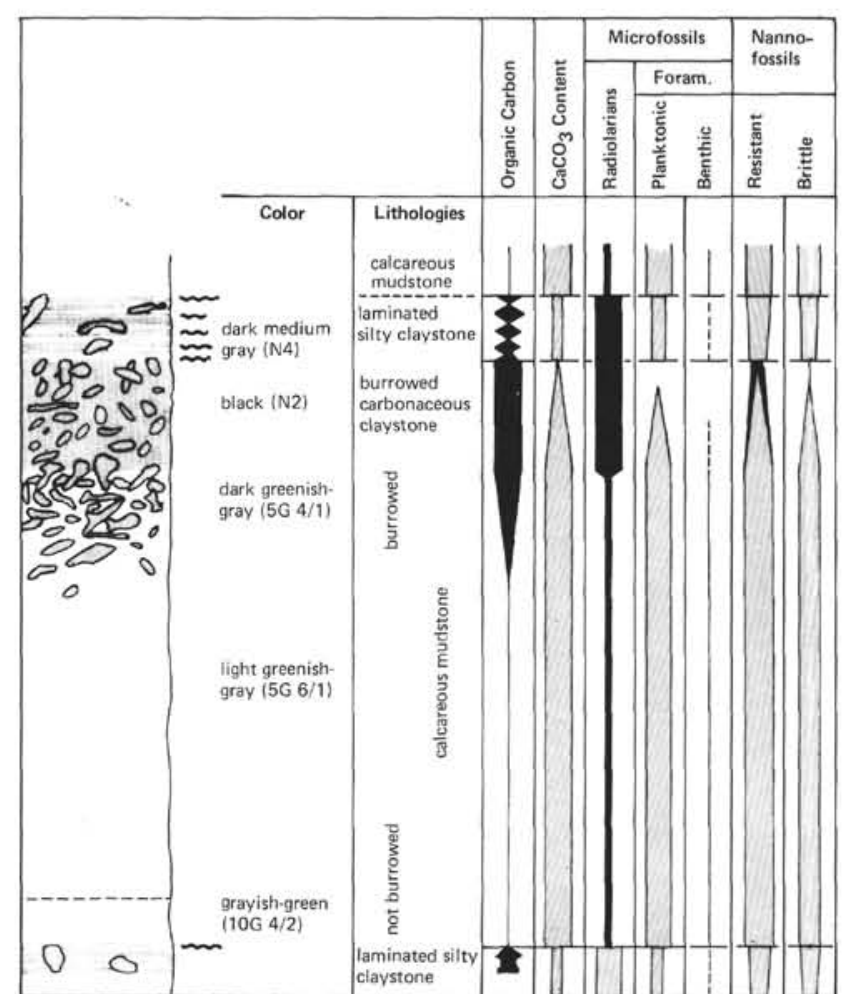

Figure 8. Diagrammatic section of a typical sequence in the lower Albian and upper Aptian of Hole 400A.

times, the bedding was disturbed by syn-sedimentary sliding and slumping, induced by deformation of the sea floor. Sedimentation ceased during a long period of the Late Cretaceous and began again in Maestrichtian times with the deposition of calcareous chalks.

The mid-Cretaceous black shale sediments were derived from several sources: the continent which provided quartz, micas, illite, and plant debris; shallower parts of the sedimentary basin which yielded pelagic calcareous muds redeposited later, probably at deeper levels than the ACD (Dupeuble, this volume); the insoluble planktonic organisms (radiolarians, diatoms, etc.) and dissolved ions such as $\mathrm{Fe}, \mathrm{Mn}$, of possible volcanic origin (Renard, this volume).

The lithology is dependent on the balance between terrestrial influences providing very fine grained terrigenous elements (quartz, clays, plant debris) and marine influences from which calcareous nannofossil-bearing chalks and marls originated. The preservation of the calcareous portions depended on the depth of the sedimentation with respect to the CCD. The abundant evidence of dissolution suggests that the sedimentation depth long remained between the CCD and the ACD.

In the mid-Cretaceous sediments of Site 400 , nowhere are there true and pure black shales; rather they are an interbedding of redeposited light colored calcareous mudstones and of more or less autochthonous black shales. The relative proportions between the two types of sediments varied with time; during the late Aptian (Gargasian), calcareous sediments were much more abundant than black shales; in the early and middle Albian, calcareous mudstones were less abundant, their $\mathrm{CaCO}_{3}$ content was lower, their planktonic foraminifer content was much less abundant, whereas terrestrial influences as indicated by the abundance in plant debris were high; in the late Albian, the balance was reversed again, favoring calcareous foraminifers and nannofossil-bearing chalks.

\section{SEDIMENTOLOGICAL STUDY OF CORES 35 TO 5, HOLE 402A (UPPER APTIAN TO UPPER ALBIAN)}

\section{Introduction}

Site 402 was the shallowest of the three sites drilled in the northern continental margin of the Bay of Biscay. It was drilled in 2355.5 meters of water. Lower Cretaceous sediments were encountered at 175 meters below the sea floor and cored from 294 meters to 469.5 meters. At Site 402 , tilted blocks, formed by rifting of a Mesozoic carbonate platform, comprise half-grabens infilled by Lower Cretaceous pre-Aptian syn-rift sediments. This sedimentary body has the shape of a wedge which pinches out towards the ocean on the crest of the underlying faulted block. The black shales do not follow this pattern and are considered to be post-rifting sediments. Seismic reflection and sedimentological interpretations suggest that they were deposited by progradation processes on the subsiding pre-Aptian platform. They are truncated at their top by a well-marked surface of erosion and/or of non-deposition, which separates Albian from Eocene beds.

\section{Main Lithological Units}

The Cretaceous sequence of Site 402 has been divided into units and sub-units (Figure 11), the main subdivisions corresponding to sharp lithological changes (Figure 12).

Within Sub-unit 3D ( 469.5 to $444.6 \mathrm{~m}$; Core 35 to Core 33, Section 2, $60 \mathrm{~cm}$; upper Bedoulian and lowermost Gargasian nannoconid-bearing calcareous mudstones), limestones predominate over marly limestones, and the two types grade progressively into each other without any sharp break. Some layers are rich in glauconite (Core 33, Section 4, $145 \mathrm{~cm}$; Core 33, Section 3, $95 \mathrm{~cm}$; Core 32, Section 2, $110 \mathrm{~cm})$. Bed thicknesses range from 0.30 to 1 meter. Carbonate contents of the limestones lie between 60 and 85 per cent, but organic carbon contents are low $(0.1$ to $0.6 \%)$. Carbonate contents in marly limestones decrease from 45 per cent in Core 34 to 25 per cent in the top of Core 33 , predicting the low carbonate contents of the underlying sub-unit. Organic carbon contents in the marly limestones is 0.6 to 0.8 per cent.

The microfacies show little variation and typically correspond to muds consisting of myriads of nannoconids pressed closely together and comprising 50 to 70 per cent of the bulk sediment (Plate 4, Figures 11, 12). Noël (1968) discovered comparable microfacies in the Vocontian Zone (French Western Alps) where they are also overlain by Gargasian black shales.

Other biogenic components are not abundant; they include planktonic and benthic foraminifers (Dupeuble, this volume), radiolarians (sometimes calcified), sponge spicules, rare pelecypods (mainly Inoceramus), rare ostracodes, and spatangue spines. Phosphate grains are scattered throughout the sub-unit. Among detrital minerals, clays are dominant with very finely divided quartz (less than 


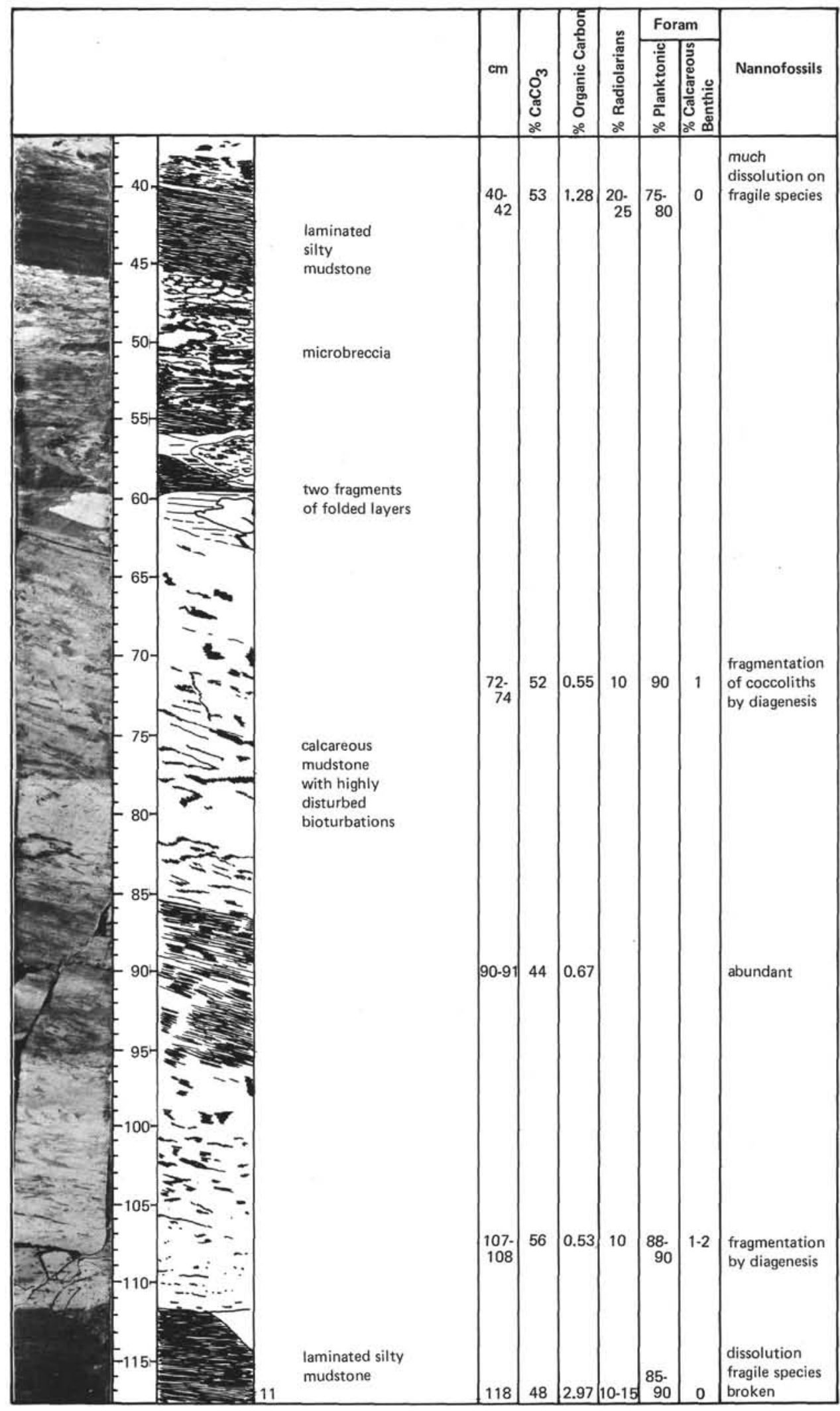

Figure 9. Slumped sequence of Hole 400A, Core 63, Section 4. 


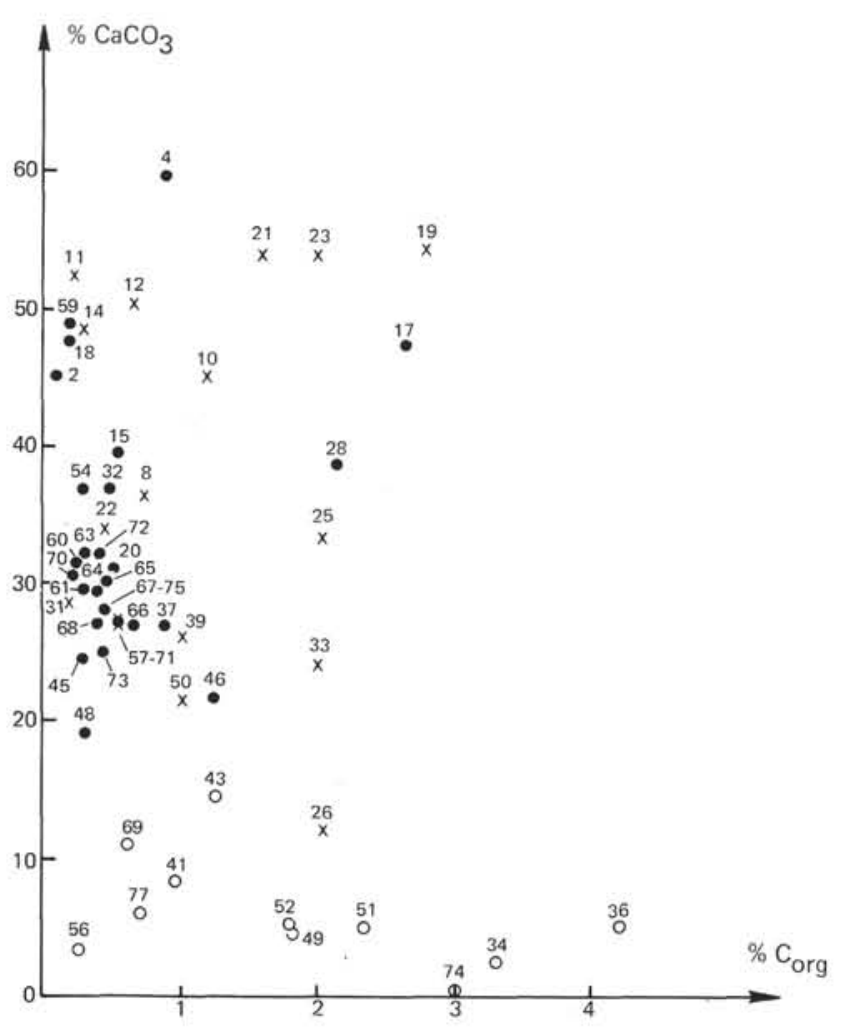

Figure 10. $\mathrm{CaCO}_{3}$ versus organic carbon contents (Hole 400A). Four groups of points may be defined, (1) a group with low $\mathrm{CaCO}_{3}$ percentages and generally high organic $C$ percentages; it corresponds to the carbonaceous claystones in the upper part of the sequences; $(2,3)$ two groups with low organic carbon content, one with high $\mathrm{CaCO}_{3}$ percentages corresponds to the slumped calcareous mudstones of the upper Albian and the other with variegated but lower $\mathrm{CaCO}_{3}$ percentages, corresponding to redeposited calcareous mudstones of upper Aptian and lower and middle Albian; (4) scattered points are representative of laminated silty claystones which partially result from reworking of carbonaceous claystones probably by bottom currents. The numbers are those of Figure 3. Circles = carbonaceous claystones; heavy dots = calcareous mudstones; crosses = laminated silty claystones.

$10 \%$ of the bulk sediment), rare muscovite, biotite, and chlorite.

In Sub-unit 3A (444.6 to 412.5 m; Core 33, Section 2, 60 $\mathrm{cm}$, to Core 29; lower Gargasian interbedded carbonaceous marly calcareous chalk and carbonaceous calcareous mudstone) the alternation of more calcareous beds and more marly beds grading progressively into each other may be comparable to those of Sub-unit 3D. In Core 33, Section 2, $60 \mathrm{~cm}$, and upwards, a sudden influx of terrigenous sediments (clays, quartz, plant debris) produces a marked change in the lithology. At this boundary, maximum carbonate content falls from 85 per cent to 47 per cent and reaches a minimum in the sub-unit of less than 20 per cent. The quartz content climbs to 25 per cent in Core 32 and organic carbon from 0.5 to nearly 3 per cent. Quartz is probably finely divided as it cannot be seen with the help of the microscope. Vegetal fragments and mica flakes are more or less abundant according to the observed thin sections. Some chalks are still rich in nannoconids (up to $35 \%$ of the bulk sediments). A few siliceous radiolarians, foraminifer tests, and shell fragments are scattered throughout. Calcareous mudstones are poor in organic remains except for plant debris (often pyritized). Bioturbation is everywhere important. The few organoclastic (wackestones) layers interbedded in this sub-unit predicate those of the overlying one. Their higher $\mathrm{CaCO}_{3}$ contents (up to 40 to $45 \%$ ) are probably due to the accumulation of $1 n$ oceramus and ammonite shell debris and of calcareous foraminifer tests. Siliceous- or zeolite-replaced radiolarians, small micrite grains, and phosphatic fragments are the other biogenic components. The entire sediment is more or less completely replaced by diagenetic siderite (see Core 32, Section 6, $150 \mathrm{~cm}$; Plate 4, Figure 8).

In Sub-unit 3B, part 2 (412.5 to $344.7 \mathrm{~m}$; Core 29 to Core 22, Section 5, $120 \mathrm{~cm}$; upper Gargasian and lower Albian marly limestones, carbonaceous marly limestones, and carbonaceous calcareous mudstones with graded bedding) bioclastic marly limestones, which are rare in the underlying sub-unit, are herein the most widespread facies. With the mudstones, they constitute graded sequences of 0.20 to $0.30 \mathrm{~cm}$ in thickness, which are easily recognizable (Core 24, Section 2) where they have not been homogenized by the strong and widespread bioturbation. The bottom of the sub-unit is marked by dominance of marls and its top by the dominance of limestones.

In Core 29 to Core 23, Section 2, the main microscopic components are micritic intraclasts and vegetal fragments within a micritic clay and calcareous matrix (Plate 3, Figure 6). Much less abundant, but omnipresent, are pelecypods and ammonite fragments, sponge spicules, radiolarians (replaced by clinoptilolite; Plate 4, Figure 5), benthic foraminifers, rare echinoderm fragments (among which mainly holothurid sclerites), and phosphatic grains. Quartz and micas are not abundant or are very finely divided.

Sub-unit $3 \mathrm{~B}$, part 2 , shows a progressive increase in the $\mathrm{CaCO}_{3}$ content and a decrease of the quartz and organic carbon contents (Figure 12) from bottom to top. The micropackstone layers of Core 22, Section 6 (Plate 3, Figure 5) and of Core 23, Section 1, are the most calcareous of this sub-unit. In this lithology undetermined micritic calcareous grains are largely dominant (40 to 60\%), followed in abundance by echinoderm fragments (holothurid sclerites [Plate 4, Figure 9], crinoid ossicles, urchin debris) and by siliceous sponge spicules. Opaque minerals, quartz grains, mica flakes, glauconite grains, radiolarians and foraminifers filled with clinoptilolite crystals, siliceous radiolarians, benthic foraminifers filled with opaque minerals, annelid tubes, and Inoceramus fragments are present but rare. The presence of echinoderms together with sparse bryozoan fragments is of essential environmental importance and is discussed later.

In Sub-unit 3B, part 1 (344.7 to $260 \mathrm{~m}$; Core 22, Section $5,120 \mathrm{~cm}$, to Core 12; lower and middle Albian slumped and graded bioclastic marly limestones and carbonaceous calcareous mudstones) sharp lithological changes occur between Sections 5 and 6 of Core 22 in the lower Albian, marked by a sudden decrease in carbonate content with 


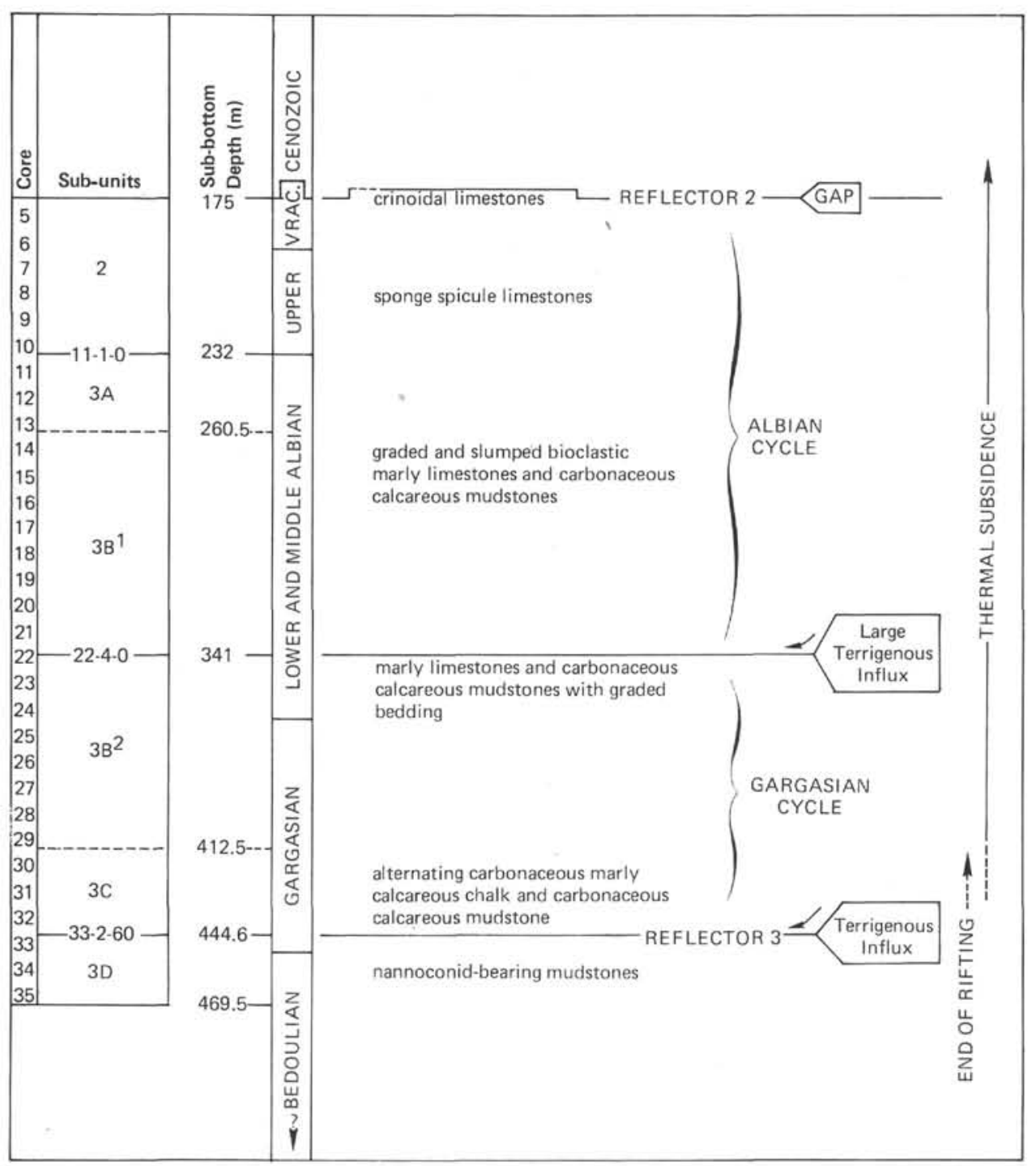

Figure 11. Cretaceous cycles within the black shales, Site 402.

matching increase in quartz and clay contents that corresponds to an increased terrigenous influx, and by the appearance of thick sequences of graded beds contorted by syn-sedimentary slumping (Figure 12).

Between Sections 5 and 5 of Core 22, the maximum $\mathrm{CaCO}_{3}$ content falls from 65 to 45 per cent. It decreases to 37 per cent in Cores 16 to 18 but rises again to more than 50 per cent in Core 13. Quartz grains are more conspicuous microscopically than in the underlying beds. Quartz content rises to 10 per cent from the base of Core 22 and averages 10 to 20 per cent, with a slight decrease towards the top of the sub-unit. The same trend is also observed for the organic carbon percentages and reflects a decrease in terrigenous influence. The organic carbon content oscillates widely between 0.5 and 1.75 per cent in the slumped beds where lithologies are different (Cores 20, 21, 22), but becomes more constant in the less disturbed intervals.

The vertical repartition of biogenic components is shown on Figure 12. The main components of the coarser parts of graded sequences are calcareous micritic fragments and quartz grains. In some layers the clinoptilolite comprises 15 to 40 per cent of the bulk, showing the importance of radiolarians in the sedimentation (Plate 3, Figures 3, 4; Plate 4, Figures 1-4, 10).

Conspicuous sedimentary features are (1) burrows, more or less pyritized or filled with glauconite, (2) graded bedding including both terrigenous and detrital material; the grading is often recognizable in spite of intense bioturbation, (3) slumping of the graded sequences; slumped beds may be up to 10 meters in thickness (Core 22, Section 5 to Core 21, Section 5, for example). The slumped lower and middle Albian beds may record the arrival of a progradation talus (the existence of which was suspected from seismic records) and coincides with a maximum in sedimentation rate. Towards the top of Sub-unit $3 \mathrm{~B}$, part 1 , the thickness of individual slumped sequences decreases and the $\mathrm{CaCO}_{3}$ contents in limestones increases, justifying the definition of Sub-unit 3A.

In Sub-unit 3A (260.5 to $232.0 \mathrm{~m}$; Cores 13, 12, 11) highly bioturbated beds, graded layers, and few slumped beds are encountered, which can hardly be distinguished from the overlying ones. The main differences are the 


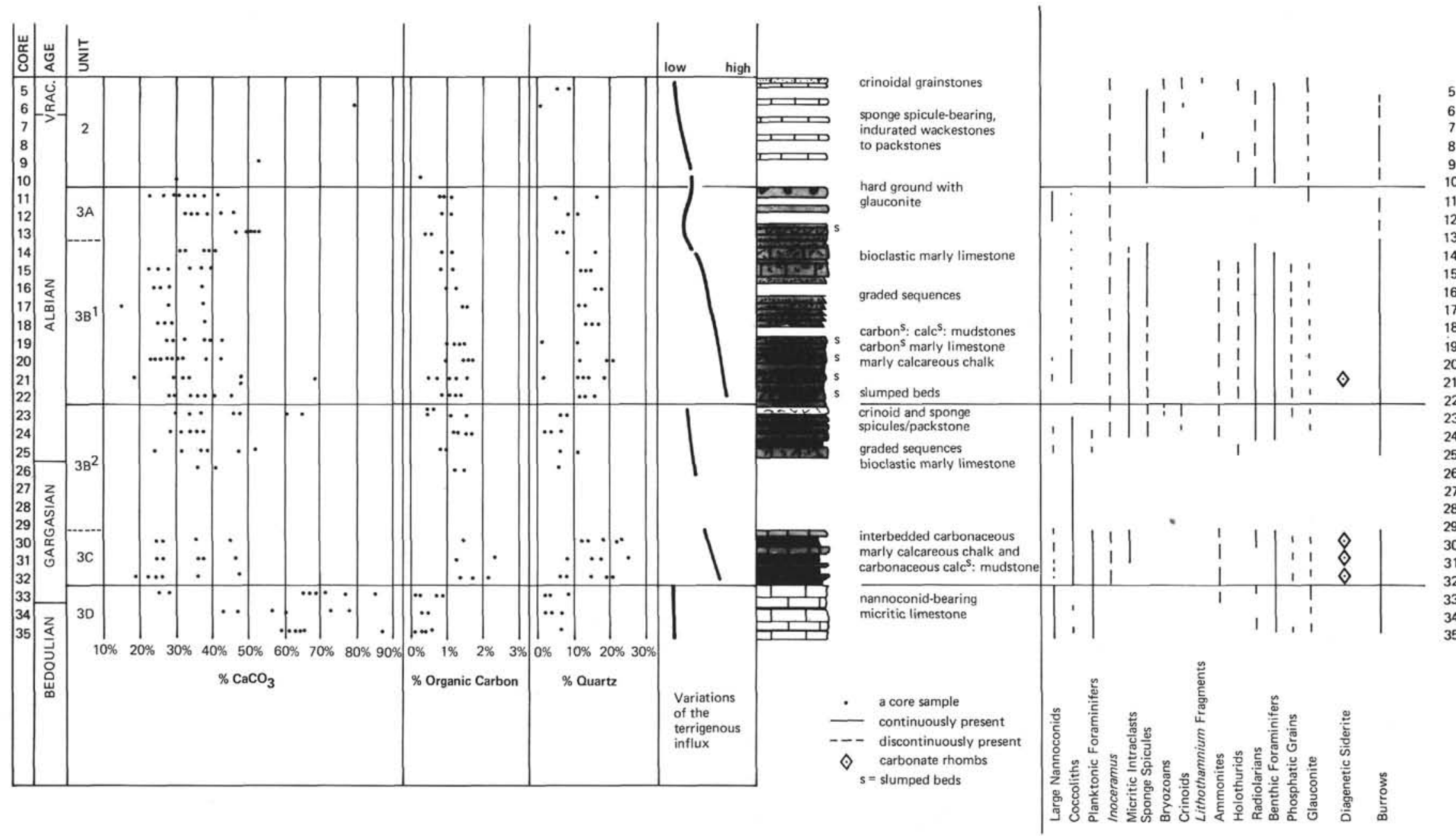

Figure 12. Temporal evolution of the main biological and mineralogical components in the Cretaceous sediments of Hole $402 \mathrm{~A}$. 
slightly lower organic carbon and higher mineral carbon percentages, the more frequent sponge spicule-bearing limestones, and the relatively more abundant glauconite. Of significance is the presence in Core 11 , Section 3 , of several hard grounds encrusted with glauconite (and ?phosphate) and perforated by boring organisms. These features suggest an upper slope environment in a basin nearly filled by the prograding shelf and that the Cretaceous sedimentary environment was, at that time, stabilized at Site 402 .

In Unit 2 ( 175 to $232 \mathrm{~m}$, Cores 10 to 5, upper Albian and Vraconian sponge spicule-bearing, indurated and often cherty limestones and other facies), the recovery was poor. Marine influences were dominant; the $\mathrm{CaCO}_{3}$ content reaches 80 per cent, but organic carbon and quartz contents do not exceed 0.5 and 10 per cent, respectively.

The main facies is light colored limestones which contain numerous sponge spicules (Plate 4 , Figures 6,7 ) in a micritic matrix (wackestone) together with few foraminifers, radiolarians tests, pelecypod shell debris, echinoderm ossicles (among which holothurids sclerites), glauconite grains, and exceptional bryozoan fragments. Silicification (chalcedony) of the matrix is frequent, leading in some places to true cherts.

In Core 6, Section 1, 15-45 cm, a peculiar micritic limestone (Dupeuble, this volume) is characterized by its abundance of Pithonella sphaerica (Kaufmann, 1865) which constitutes up to 90 per cent of biogenic remains, together with rare Pithonella ovalis (Kaufmann, 1865), small echinoderm fragments (10\%), and few Hedbergella (Plate 3 , Figures 7, 8, 9). These pithonellids, which have been kindly determined by J. M. Villain, are indicative of an external carbonate platform (Villain, 1977).

At the top of the unit (Core 5, Section 1), crinoidal grainstones (Plate 3, Figures 1,2) are present and consist of dominant crinoid ossicles together with some echinoids, holothurids, bryozoans, sponge spicules, and foraminifers (Hedbergella). Some facies are enriched in Lithophyllum fragments (Dupeuble, this volume) that are probably reworked.

Crinoids are known (Bernoulli and Jenkyns, 1974; Schlager, 1974) to have dwelt on the upper break of submarine slopes in the Mesozoic seas. Bryozoans are widespread on the outer shelf, seaward from an oolitic bar if present. Lithophyllum lived in the photic zone. Even if the crinoids had been displaced here from their original habitat, their association with displaced bryozoan and algae is highly indicative of top-of-slope and outer shelf environment. Proximity to the Cretaceous shelf edge of Site 402 seems reasonable.

In spite of the poor recovery, which does not allow for a more precise investigation, it may be noted that the grains are well sorted and much coarser than in the overlying units. The intergranular porosity is high and the cement, where present, is synaxial sparite. Such observations suggest that the original calcareous sand has been sorted and cleared of its clay fraction by water movement. In this environment, it may have been not far from the bottom of the wave agitation zone. This means that the sediment might have been reworked from a neighboring high energy zone suggesting, in turn, that the paleodepth might have lain between 50 and 100 meters.

\section{Evolution of the Environmental Conditions During the Black Shale Episode of Site 402}

\section{Definition of Sedimentary Cycles}

From sedimentological evidence, the Cretaceous of Hole $402 \mathrm{~A}$ can be divided into two sequences (Figure 11). The lower sequence is underlain by marly calcareous mudstones consisting mainly of nannoconids (late Bedoulian). The boundary between them, located at a depth of 444.6 meters (Sample 33-2, $60 \mathrm{~cm}$ ), is sharp and corresponds to reflector 3 (Site 402 Chapter). It is manifested as a sudden increase of terrigenous components coupled with a decrease of the carbonate content and marks the onset of the black shale deposition, which replaced deposition of calcareous ooze.

The lower sequence corresponds to lithologic Sub-unit $3 \mathrm{C}$ and the lower part of Sub-unit $3 \mathrm{~B}$ and is of Gargasian and earliest Albian age. Although there was good recovery in its lower parts (Cores 30, 31, 32) and upper parts (Cores $23,24,25)$, only the core catchers were recovered in the middle. There is a distinct change, from the bottom to the top of this sequence, showing decreasing terrigenous influx and increasing calcareous sedimentary supply. From Core 32 to Core 23 , the maximum $\mathrm{CaCO}_{3}$ content rises from 45 to 65 per cent, the minimum $\mathrm{CaCO}_{3}$ content rises from 19 to 20 to 30 per cent, the organic carbon content decreases from 1.4 to 2.7 to 0.5 to 1.5 per cent, and the quartz content decreases from as high as 25 per cent to less than 10 per cent.

A discontinuity between the lower and the upper sequences is located at 344.7 meters of depth (Sample 22-5, $120 \mathrm{~cm}$ ) and is characterized by the slumped black shales resting upon previously deposited calcarenites, on an inclined, probably erosional surface.

The upper sequence, mainly of Albian and Vraconian age, corresponds to the upper part of Sub-unit 3B, Sub-unit $3 \mathrm{~A}$, and Unit 2 (Cores 11 to 22 ). Sub-units $3 \mathrm{~B}$ and $3 \mathrm{~A}$ were satisfactorily recovered but not Unit 2 . Within this sequence there is again a clear trend from sediments dominated by terrigenous influx at the base to near exclusively calcareous biogenic deposits at the top. From Core 22 to Core 5, the $\mathrm{CaCO}_{3}$ content climbs from 25 to 45 per cent to 80 per cent, the organic carbon content decreases from 1.5 to 1.7 (to less than $20.1 \%$ ), and the quartz content decreases also from 20 to 5 to 8 per cent. The uppermost boundary is an erosion surface between Eocene and Vraconian beds (reflector 2, Site 402 Chapter).

\section{Evolution of the Environment Within Each Sequence}

The succession of the sedimentary features within the upper sequence, from bottom to top, comprises (1) slumped marly limestones and calcareous mudstones, (2) graded sequences interbedded with slumped beds, (3) hard grounds, and (4) indurated, relatively coarse packstones to grainstones. The dominant biogenic components are ammonites, more or less fragmentated within mudstones, micritic grains (micritized shell fragments and crinoid ossicles ?) within graded bioclastic marly limestones, plus subordinate shells of Inoceramus, sponge spicules and holothurian sclerites, sponge spicules within wackestones to packstones, pithonellids (localized in a 30 -cm-thick layer only), and 
crinoid ossicles and urchin fragments, associated with a few bryozoans and enriched locally in Lithophyllum.

An upslope trend is clearly shown (Figure 13). The slumped beds correspond to accumulation near the foot of a short slope which was a part of the continental shelf; the interbedded graded and slumped strata correspond to the spreading of sediment on this slope, and the hard grounds indicate the upper part of this slope.

The distribution of the biogenic components along a theoretical slope (Figure 13) is in good agreement with that classically known (Bernoulli and Jenkyns, 1974; Schlager, 1974) from the Mesozoic seas where ammonites were dominant in the more basinal facies. In contrast, abundant echinoderms, red algae, and pithonellids (and the presence of few bryozoans) are indicative of the upper part of the slope, in relatively shallow depths.

It thus seems clear that, within this Albian/Vraconian cycle, the progressively shallower depths of deposition indicate progressive infilling of the basin. Moreover, higher sedimentation rates occurred in the lower and middle $\mathrm{Al}$ bian, where the slumped beds are thicker and more numerous, and when the terrigenous sedimentary supply was at a maximum.

The Albian sequence, well documented by good recovery, has a wide range of lithologies and can be used for comparison with the underlying Gargasian cycle. The balance between terrigenous and marine influences shows the same evolution in both cycles. In the Gargasian cycle, the lower beds (Cores 27 to 29) are symmetrical alternations of more calcareous and more marly beds, rich in ammonites (Renz, this volume). This alternation is indicative, in the slope context, of distally redeposited argillaceous and calcareous muds (Beaudoin, 1977). The asymmetrical, graded, small-scale sequences appearing in the upper part of the main sequence (especially in Core 24) are clearly of turbidite origin. The beds toward the top, which are coarser grained and richest in carbonates, contain numerous micritic grains and sponge spicules, rare bryozoans, and are enriched in crinoids and other echinoderm fragments relative to the underlying beds. This association resembles that observed in the uppermost layers of the Albian sequence (Core 5-1; Plate 3, Figures 1, 2).

Thus, the comparison of the Gargasian and Albian sequences strongly suggests that both developed from footof-slope or distal ammonite-bearing calcareous mudstones to up-slope crinoid-bearing calcarenites. This slope was not, of course, the extended continental slope of Brittany, but only a part of the continental shelf. The Albian sequence is the more complete but the Gargasian one is more remote from the shelf edge and probably was truncated at its summit by large slumped masses in early Albian times. Although the Albian sequence is interrupted by an erosion surface, the general trends are the same.

\section{Paleodepth Considerations}

For the reconstruction of paleodepth, of special interest is the presence of relatively abundant and entire Inoceramus shells (together with their debris, of course) which, according to Thiede and Dinkelman (1977), lived between 100 and 500 meters depth. Inoceramus is not present upwards of Cores 10 to 11 , which matches well with the proposed value of 50 to 100 meters for the deposition of the crinoidal limestones of Core 5. It follows that the sea-bottom depth could not have been deeper than the value of the thickness of the individual cycle plus 50 to 100 meters, i.e., 320 to 370 meters, compaction not taken into account.

\section{Tectonic and Sedimentary Evolution of the Basin}

The Bedoulian nannoconid-bearing pelagic limestone may be representative of syn-rift deposits in the area of Site 402. Indeed, seismic reflector 3 , which coincides with the boundary between the nannoconid-bearing limestones and the black shales, is displaced by small faults whereas the top of Albian is not (Site 402 Chapter). This observation and others (Montadert et al., this volume) have been used to date the end of the rifting phase and thus the beginning of spreading and thermal subsidence of the margin as postearly Aptian.

In the early Gargasian, a major sedimentary break occurred, marking erosion of the continent and manifested in an influx of terrigenous material, including terrestrial organic matter (Figure 12). These sediments were deposited and distributed by short way turbidites and by progradation of calcareous biogenic sands and muds over the surface corresponding to reflector 3. During early Albian, the terrigenous influx progressively diminished and, it its stead, calcareous sediments originating from parts of the continental shelf which were rather shallow and open to the sea (external shelf environment) were redeposited in increasing proportions under relatively shallow depths.

In early Albian times, a second break occurred (Figures 11 and 12). Mainly terrigenous material was deposited on a probable erosion surface that cut the underlying beds. This surface may be represented on the seismic record (Site 402 Chapter) through Site 402.

Because slope indicators (slumped beds, graded sequences) occur in the lower Albian section, and because upper slope and external shelf environments have been shown to exist during the late Albian and Vraconian, it may be inferred that the second sequence represents a prograding shelf. As the external shelf surface advanced, biogenic calcareous sedimentation, derived mainly from echinoderms, accompanied by sponge spicules and by subordinate red algae and bryozoans, became progressively dominant. Unfortunately the available seismic data do not supply details within each depositional sequence, nor of their relationship, making uncertain our knowledge of progradation processes.

Late Aptian (Gargasian) and Albian deposits clearly can be interpreted as two successive depositional sequences (Figures 12, 14) in the sense of Mitchum et al. (1977). We suggest that this evolution is linked not only with local factors (such as the evolution of a subsiding margin), but is related also to geological events of more global significance such as relative variations of the sea level, as shown for comparable cases by Vail et al. (1977).

Of particular importance for the interpretation is the environmental evolution of each depositional sequence from deeper terrigenous to shallower carbonate deposits, within the context of a thermally subsiding margin. The seaward migration of shallower facies (Figure 14), which indicates a regression (Vail et al., 1977), was possible because the 


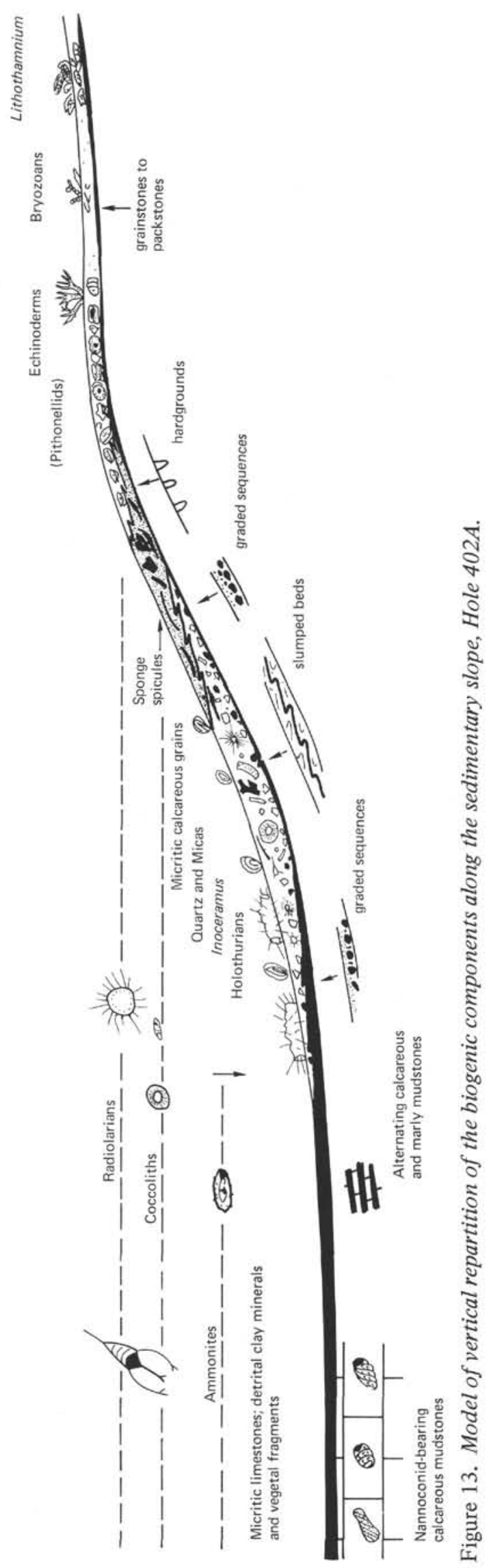

sedimentation rate - mainly due to terrigenous influx was high enough to compensate the thermal subsidence of the margin.

Moreover, the beginning of the first sequence between early and late Aptian time coincides exactly with the death of an extended carbonate platform of Bahamian type (Arnault-Vanneau and Arnault, 1976) in the Urgonian domain of the Western French Alps. In Aquitaine, such an event is recorded by the unconformity of upper Aptian on lower Aptian (B.R.G.M., 1974). From general compilation data, Vail et al. (1977) indicate that, also in Aptian time, a short relative fall in sea level occurred, followed by a continuous rise until Cenomanian times.

It is therefore probable that the onset of black shale deposition in Biscay between early and late Aptian time is linked not only to the beginning of (thermal) subsidence of the Atlantic margin, but to a more global event, perhaps a eustatic change of sea level. The repetition of the seaward migration of shallow facies (indicating regression) and high terrigenous influx on a still subsiding margin shown by the two sequences may be explained as a result of sharp increase in subsidence rate at their mutual time boundary. It is well established that the Albian green sands are transgressive in many places of western Europe, due perhaps to high sea-level stance. Based on lithology of the comparison of the two sequences, and on the prevailing concepts of Vail et al. (1977), we suggest that a progressive sea-level rise associated with the subsidence of the margin was responsible for the deposition of the upper prograding unit, with a repetition of deeper facies deposited upon shallower ones.

\section{COMPARISON OF SEDIMENTOLOGICAL CHARACTERISTICS AND EVOLUTION OF HOLES 400A AND 402A}

\section{Environmental Conditions}

Stratigraphic correlation of the two holes is summarized on Figure 15 (after Dupeuble, this volume). The black shales of Site 400 were deposited in deep-sea abyssal plain conditions, probably near the calcite compensation depth and certainly deeper than the aragonite compensation depth. The instability of the sea bottoms is demonstrated by the slumped Albian beds.

The black shales of Site 402 were deposited at the front of two superimposed prograding shelves. The lower, of mainly late Aptian age, is separated from the upper one, of Albian age, by a probable erosion surface. Depth of deposition was certainly shallower than 300 to 500 meters, as is shown by mineralogical (Mélières, this volume) and paleontological considerations.

\section{Mineralogy}

Accurate mineralogical determinations and comparisons have been performed by Mélières (this volume) on selected sequences at both sites.

From paleontological and thin-section data, differences between primary mineral contents, resulting from different depths of sedimentation, have been observed. Aragonite is completely absent from Site 400 . There are variations of the 


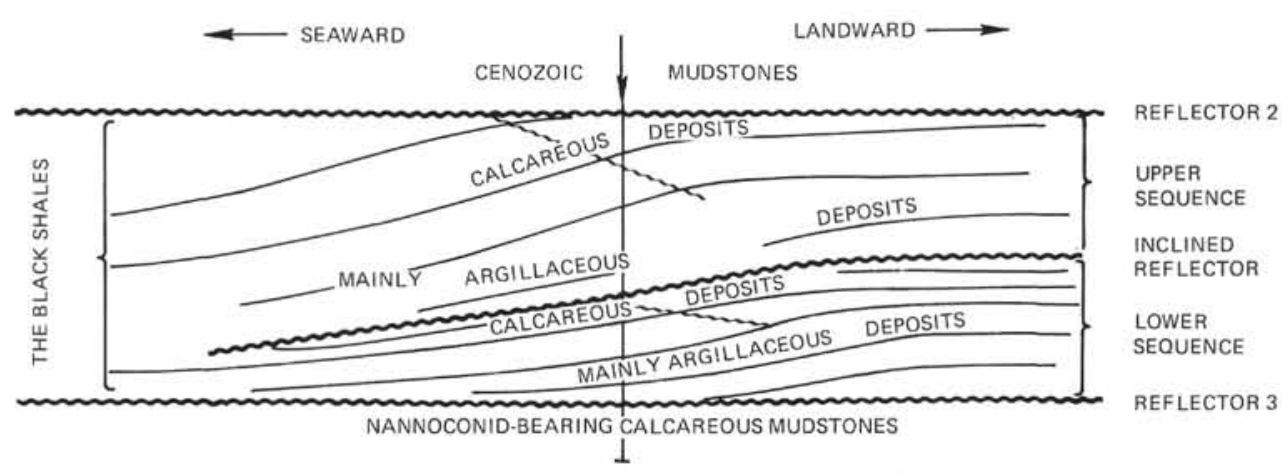

Figure 14. Structural interpretative section of the black shales at Hole $402 \mathrm{~A}$.

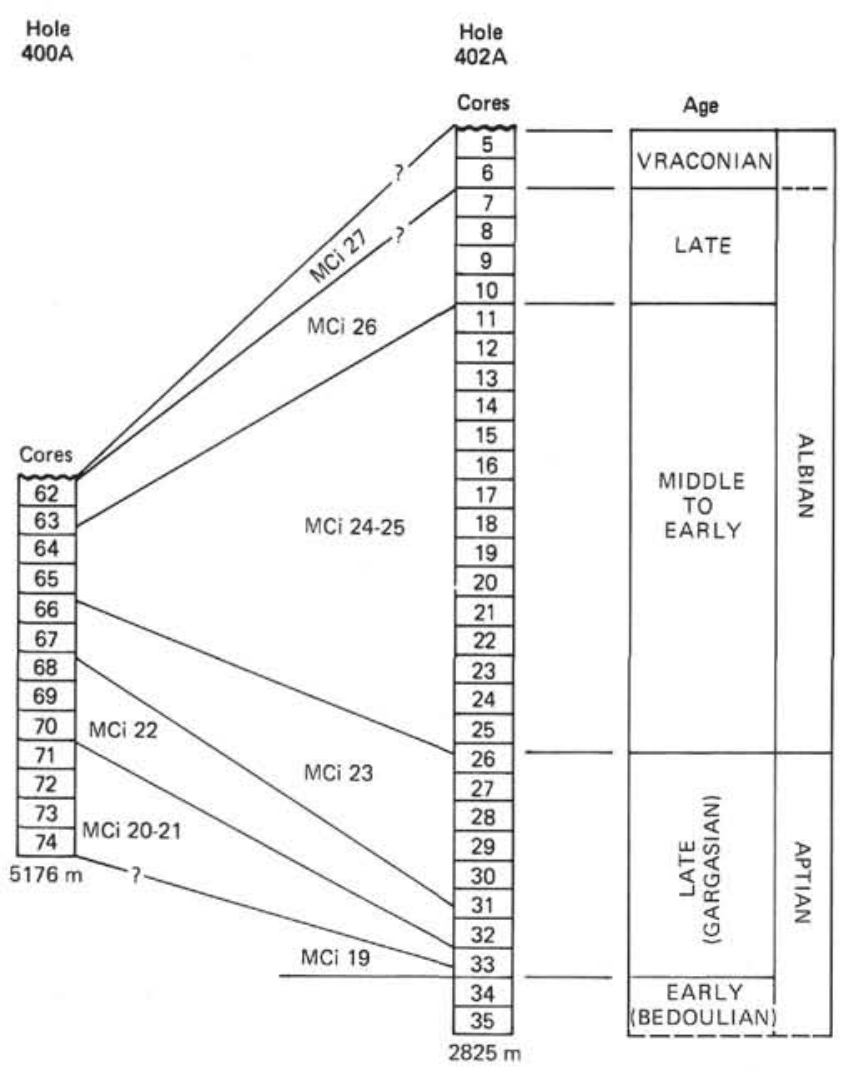

Figure 15. Stratigraphic correlation of the Cretaceous black shale successions of Holes $400 \mathrm{~A}$ and $402 \mathrm{~A}$, with foraminifer zones (after Dupeuble, this volume).

calcite content on a metric or decimetric scale, from 30 to 40 per cent to less than 5 per cent at Site 400 (Figure 7), but not at Site 402. Glauconite is rare at Site 400 , and then bound only within redeposited sediments; it may be abundant in some horizons of Site 402 and linked to hard grounds. Phosphatic grains are scattered everywhere. Amorphous silica, which is common at Site 402 in radiolarian tests (Plate 4, Figures 1-4) and in sponge spicules (Plate 4, Figures 6,7), is almost completely replaced by clinoptilolite in the deeper site (Plate 1, Figure 5; Plate 2, Figures 1-3, 5, 6).
Among diagnetic minerals, clinoptilolite is abundant at both sites, but is differentially concentrated in the carbonaceous claystones of Site 400 (Mélières, this volume) which have been depleted of carbonates by dissolution. Opaque minerals are widespread and are often concentrated in the chambers of foraminifers or linked to bioturbations. Siderite is rare at Site 400 , but at Site 402 may replace more or less completely the primary sediments (Plate 4, Figure 8).

Detrital components are nearly the same at both sites, but are coarser in the shallower one: quartz, white micas, and vegetal fragments are dominant; chlorite, green (and more rarely brown) biotite, and feldspars are much less frequent; and tourmaline is present in a few horizons at both sites.

\section{Biological Components}

In the deeper site, fossil remains are those which reach the deep sea floor and are thus poorly diversified. Radiolarians and nannofossils are the most widespread components, together with some foraminifers in calcareous beds. Sponge spicules are exceptional and are calcitized if present. Reworked urchin spines and fragments of crinoid ossicles have been noticed also (Table 3 ).

At Site 402, fossil debris is abundant and diversified. Its vertical distribution is summarized on Figures 12 and 13. Fossils comprise abundant ammonites (entire and fragmentated, suggesting the vicinity of the shore; Renz, this volume), gastropods, pelecypods (Inoceramus), sponge spicules, echinoderms, red algae, bryozoans, and of course foraminifers and nannofossils. The relative abundance and the variety of this debris are due to the proximity of shallow environmental conditions.

\section{Sedimentary Features}

Graded beds (Site 402), mud flow sequences (Site 400), slumped beds (Figure 9), laminae, perforated hard ground with glauconite, and ubiquitous intense bioturbation are the principal sedimentary features.

\section{Depositional Processes}

The evidence of syn-sedimentary slopes is shown by the presence of slumped beds at both sites. Deposition by turbidity currents at Site 402 , on the foreset or prograding 
shelf, is distinct in beds where typical graded and erosive sequences have been undisturbed by bioturbation.

The main depositional process for the emplacement of sediments at Site 400 is interpreted here as very fine grained turbiditic flows (mud flows) in an abyssal environment. Metric alternations of carbonaceous claystones and of calcareous layers which are poor in organic carbon previously have been interpreted in terms of rhythmic and frequent climatic changes on the basis of comparison with Holocene deposits such as the varves in Scandinavian glacial lakes. Another explanation of such alternation is redeposition by gravity flows. The mode of emplacement of sediments at Site 400 by mud flows is documented both by local observations and comparisons with other sites.

Calcareous mudstones at Site 400 , which are interpreted here as the base of each individual sequence (Figure 8), are in sharp erosional contact with, and cut bioturbations on top of, the underlying units. Carbonate depletion, dissolution of calcareous tests, and strong bioturbation characterize the claystones which are interpreted as lying at the top of individual sequences and have therefore been in longer direct contact with corrosive bottom sea waters.

There is no noticeable graded bedding in such sequences, probably because of the fine grain size of the initial sediment and/or of the remoteness of the deposition site from the sources. However, in other DSDP sites of the North Atlantic (Hole 398D, de Graciansky and Chenet, in press; Sites 367 and 386, personal observation), comparable rhythmic black shales have been observed, but with graded silts and sands at the base of sequences. In shallower conditions, in the Vocontian domain of the Western French Alps where thick and extended mid-Cretaceous black shales have been deposited, alternation of more argillaceous and more calcareous mudstones have been demonstrated to be of turbidite origin (Beaudoin, 1977).

\section{Temporal Evolution of Sedimentary Conditions}

Changes in sedimentary conditions are manifested by several discontinuities marked by a sudden increase in the terrigenous sedimentary influx relative to the calcareous supply. The early Gargasian discontinuity is widespread, at least at the European scale (Vail et al., 1977); it may correspond to the onset of a transgression, which may be due to eustatic movements, that became more general in the Late Cretaceous.

The early Albian discontinuity corresponds to the arrival of a huge volume of detrital material on the north Biscay margin (Sites 400 to 402), the Iberian margin (Site 398, de Graciansky and Chenet, in press), as well as on the continent. The detrital Green Sands and Gault in western Europe correspond to the Albian. Thick black shales of Albian age overlie the calcareous beds of Clansayes (boundary between Albian and Aptian) in the Vocontian domain in the southeast of France (Goguel, 1944-1945).

The end of the black shale episode is marked by a general sedimentary gap in the Upper Cretaceous of the North Central Atlantic, which begins in the Vraconian at Sites 400 and 402 .

These three discontinuities define two main sequences at Site 402 , each one corresponding to a prograding shelf. Within each sequence, conditions grade from the deeper, argillaceous upper slope, to the shallower and the more calcareous environments (Figures 12 and 13). Such sequences may be due to the combined influence of a regional transgression on the continent and to the (thermal) subsidence of the margin.

The evolution of the sedimentary supply at Site 400 during the Gargasian is somewhat different from that of the neighboring Site 402 and is more similar to that of Site 398 on the outer Iberian margin (Figure 16) as noted by Deroo et al. (this volume). It seems that comparable conditions existed in the abyssal parts of the young Atlantic at that time.

The sedimentary evolution during the Albian is clearly marked at Sites 400, 402, and Hole 398D (de Graciansky and Chenet, in press) by the dominant terrigenous influx in early Albian time that changed to pelagic calcareous and biogenic deposition in the Vraconian (Figure 16).

A similar evolution thus exists for the Albian period on remote points of the Atlantic European margin. If this is confirmed by other observations, it may be assumed that it reflects the prevailing environmental conditions in western Europe and the eastern Atlantic. The processes concerned are related to the biogenic productivity of sea water, the erosional activity on the continent, the rate of subsidence and eustatic changes in sea level.

The problem concerning the dark color of the black shales remains unresolved. It is clear that the darker colors are related to the higher organic matter content, but this material was already altered prior to deposition as shown by its low hydrogen index (Deroo et al, this volume), and the alteration may have taken place partly on the continent. Extreme reducing conditions in the environment of deposition were not essential to the preservation of this organic matter in the sediment whereas they would have been essential if the dark colored sediments were true sapropels, i.e., if the organic matter was basically of marine origin.

If results from the two sites can be regarded as being representative of the environment of the whole margin, reducing conditions did not prevail during Aptian-Albian time in this part of the northeast Atlantic. In the narrow, youthful Bay of Biscay, either on the shelf or in deep water, welloxygenated circulation, unfavorable for the preservation of marine organic matter, existed. Nevertheless, in other parts of the Atlantic, true sapropels exist (Tissot, in press) indicating reducing conditions. The widespread Lower Cretaceous black shale deposition therefore cannot be expressed by a single, simple explanation. Describing and defining the nature of the organic matter and the way it was implaced in marine sediments are a prerequisite before discussing any global implication of black shale deposition.

\section{ACKNOWLEDGMENTS}

The authors thank J. M. Villain (CFP total) for determination of Pithonella, Prof. O. Renz for determination of ammonites, and D. Mercier for his collaboration in core examination and drawings and photographs. The authors had many helpful discussions with F. Mélières, and are grateful to Dave Moore and Dan Fornari (DSDP) who facilitated re-examination and sampling of the cores. Thanks are due to David Roberts, who kindly edited the manuscript. This study was partly undertaken (P.C. de G.) under CNEXO Contract 78/5669 "Paleoenvironment of North Atlantic black shales." 
TABLE 3

Main Microscopic Components of Some Lithologies, Hole 402A

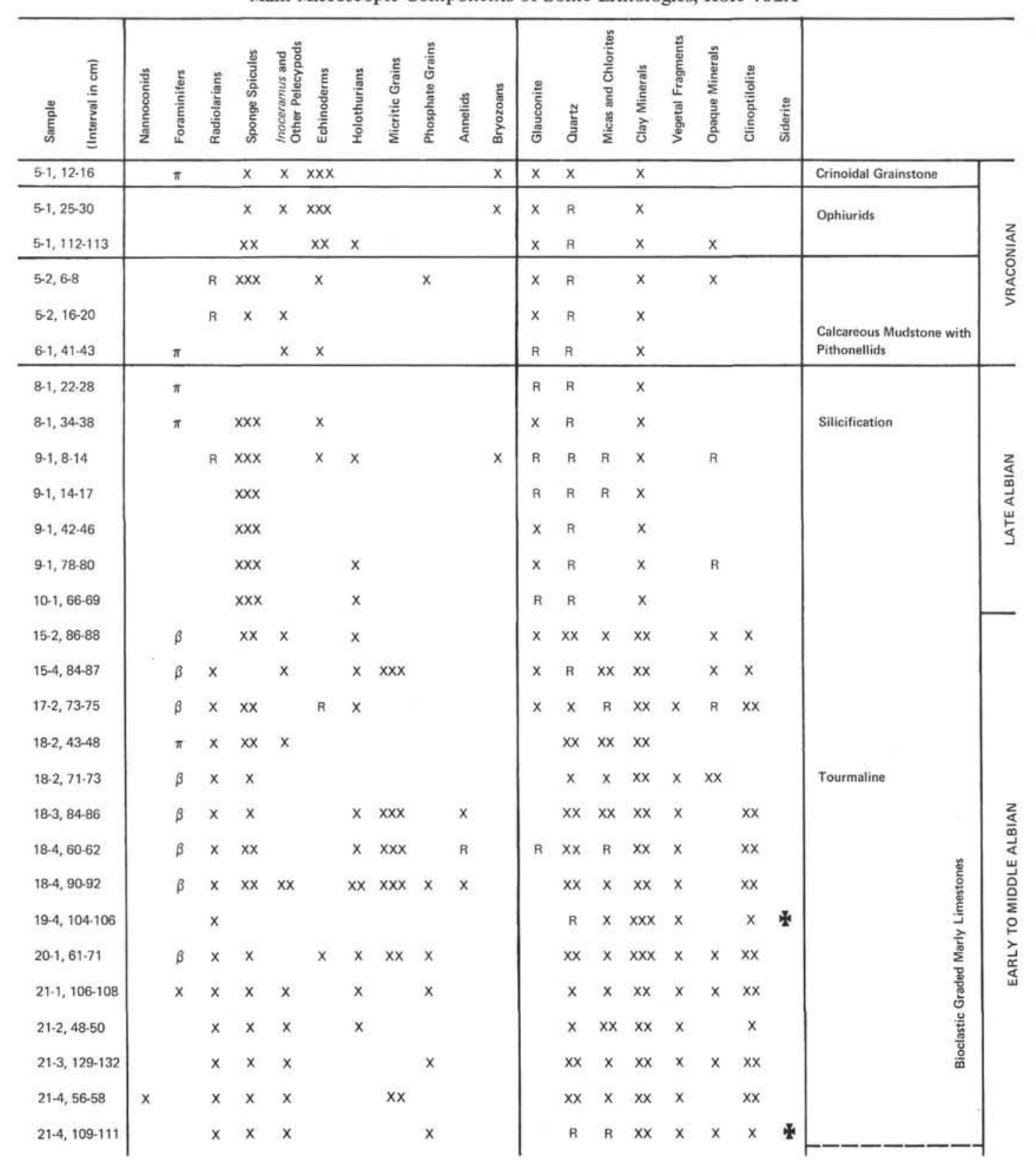




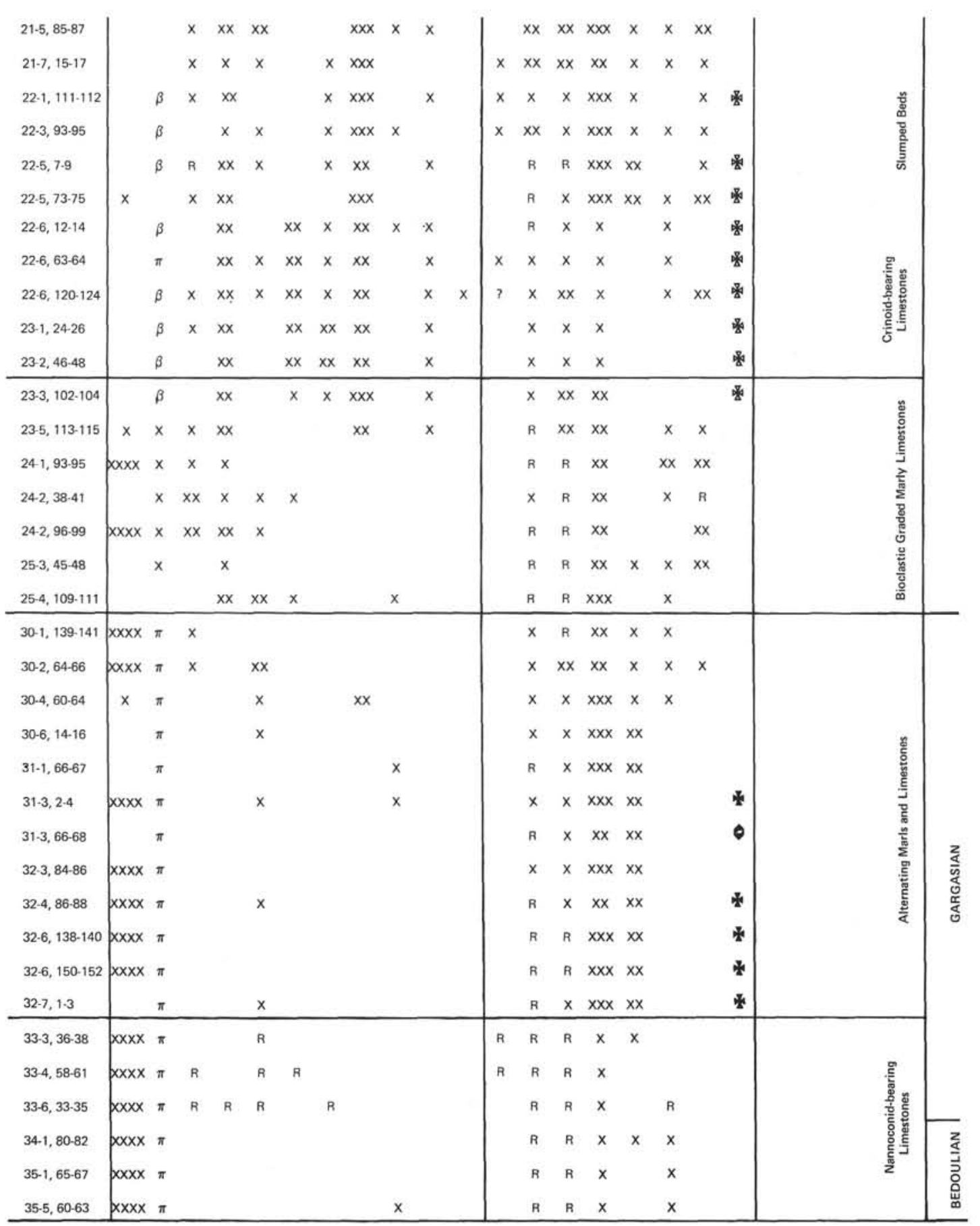




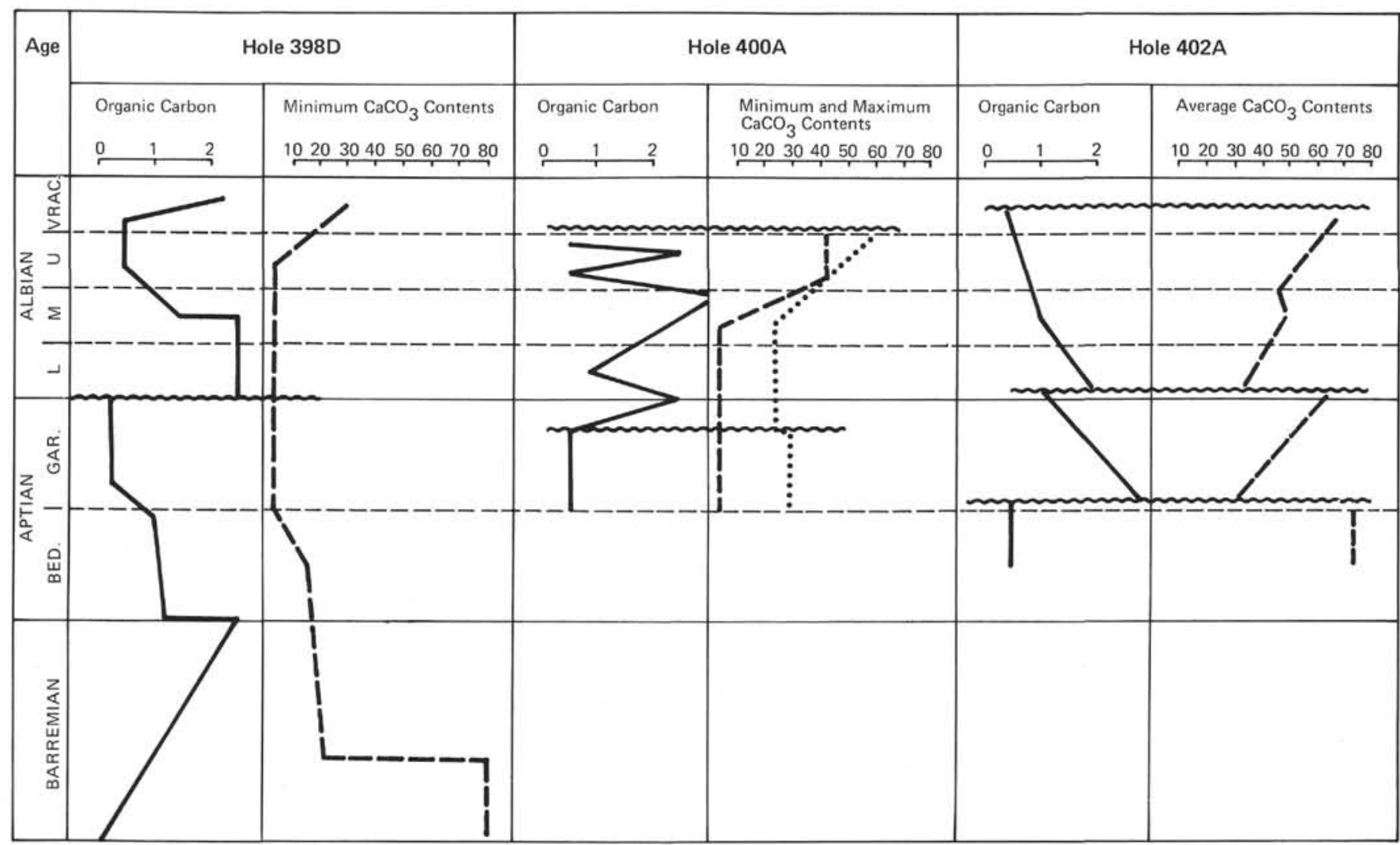

Figure 16. Compared evolution of organic carbon and $\mathrm{CaCO}_{3}$ contents at Hole 398 (Iberian margin) and Holes $400 \mathrm{~A}$ and $402 A$.

\section{REFERENCES}

Arnault-Vanneau, A. and Arnault, H., 1976. L'évolution stratigraphique du Vercors au Barrémien et à l'Aptien inférieur (chânes subalpines septentrionales, France), Géologie Alpine, v. 52 , p. $5-30$.

Beaudoin, B., 1977. Méthodes d'analyse sédimentaire et reconstitution du bassin: le Jurassique terminal-Berriasien des chaines subalpines méridionales, Thèse U.E.R. Sci. de la Terre, Université de Caen.

Bernoulli, D. and Jenkins, H.C., 1974. Alpine, Mediterranean and Central Atlantic Mesozoic facies in relation to early evolution of the Tethys, SEPM Spec. Publ. 19, p. 129-160.

Bouma, A., 1965. Sedimentology of some flysch deposits: a graphic approach to facies interpretation: Amsterdam (Elsevier).

B.R.G.M., E.L.F.-R.E., ESSO Rep, S.N.P.A., 1974. Géologie du Bassin d'Aquitaine: France (B.R.G.M.).

Brouwer, J., 1965. Agglutinated foraminiferae faunas from some turbiditic sequences, K. Nederl. Akad. Wetensch. Proc., v. 68, p. 309-334.

Cotillon, P., 1971. Le Crétacé inférieur de l'arc subalpin de Castellane entre l'Asse et le Var; Stratigraphie et Sedimentologie, Mem. Bureau. Rech. Géol. Min., no. 68, p. 1-313.

Goguel, J., 1944-1945. Contribution à l'étude paléogéographique du Crétacé inférieur dans le SE de la France, Serv. Carte Géol. France Bull., no. 215.

de Graciansky, P.C. and Chenet, P.Y., in press. Sedimentological study of Cores 138 to 56 (upper Hauterivian to lower Cenomanian); an attempt at reconstruction of paleoenvironments. In Ryan, W.B.F., Sibuet, J.C., et al., Initial Reports of the Deep
Sea Drilling Project, v. 47, Part 2: Washington (U.S. Government Printing Office).

Habib, D., in press. Sedimentology of palynomorphs and palynodebris in Cretaceous carbonaceous facies, South of Vigo Smt, Leg 47B, Hole 398D. In Ryan, W.B.F., Sibuet, J.C., et al., Initial Reports of the Deep Sea Drilling Project, v. 47, Part 2: Washington (U.S. Government Printing Office).

Hesse, R., 1975. Turbiditic and non turbiditic mudstones of Cretaceous flysch sections of the East Alps and other basins, Sedimentology, v. 22, p. 387-416.

Kuenen, P.H., 1968. Turbiditic currents and organisms, Eclog. Geol. Helv., v. 61, p. 525-544.

Moulade, M., 1974. Zones de foraminifères du Crétacé inférieur mésogéen, C.R. Acad. Sci., Paris, v. 278, p. 1873-1876.

Noël, D., 1968. Nature et genèse des alternances de marnes et de Calcaires du Barrémien supérieur d'Angles (fosse vocontienne, Basses Alpes), C.R. Acad. Sci., Paris, v. 266, p. 1223-1225.

Ricci-Lucchi, F., 1975. Depositional cycles in two turbiditic formations of Northern Apennine (Italy), J. Sed. Petrol., 45, 1, p. 3-43.

Schlager, W., 1974. Preservation of cephalopods skeletons and carbonate dissolution of ancient tethyan sea floors. In Hsü, K.J. and Jenkyns, H.C. (Eds.) Blackwell, Pelagic Sediment, on Land and under the Sea: Spec. Publ. of the I.A.S.

Thiede, J. and Dinkelman, M.G., 1977. Occurrence of Inoceramus remains in the late Mesozoic pelagic and hemipelagic sediments. In Talwani, M., Udintsev, G. et al., Initial Reports of the Deep Sea Drilling Project, v. 38: Washington (U.S. Government Printing Office), p. 899-910.

Tissot, B., in press. Organic matter in Cretaceous sediments of the North Atlantic. Contribution to sedimentology and palaeogeography, Second Maurice Ewing Mem. Symp. Proc. 
Vail, P.R., Mitchum, R.M., Jr., Thompson, S., III, 1977. Global cycle of relative changes of sea level. In Payton, C.E. (Ed), Seismic stratigraphy. Application to hydrocarbons explorations: Tulsa (Am. Assoc. Petrol. Geol.), p. 83-99.
Villain, J.M., 1977. Les Calcisphaerulidae, architecture, calcification de la paroi et phylogenèse, Paleontologica Abt., v. 159, p. 139-177.

Weidman, M., 1967. Petite contribution à la connaissance du flysch, Bull. Lab. Géol. Lausanne, v. 166, p. 1-6. 


\section{PLATE 1}

Thin-Section Microphotographs, Hole 400A

Figures 1-6 Carbonaceous claystones; upper part of the sequences.

1. Sample $65-2,96-97 \mathrm{~cm}(\times 16)$ : Low magnification view of a carbonaceous claystone.

2. Sample $64-4,55-57 \mathrm{~cm}(\times 150)$ : Detail of another sample of the same type as Figure 1. Numerous clinoptilolite crystals and vegetal fragments (opaque grains) are scattered within a mainly argillaceous matrix. Very small quartz, white micas, and rare calcite and phosphate grains are present also in the same section. In this sample $\mathrm{CaCO}_{3}=14.3$ per cent; organic $\mathrm{C}=1.28$ per cent.

3. Sample $66-4,55-57 \mathrm{~cm}(\times 150)$ : Opaque vegetal fragments and clinoptilolite crystals scattered within an argillaceous matrix.

4. Sample $66-2,29-30 \mathrm{~cm}(\times 50)$ : Cluster of zeolitic crystals within a carbonaceous claystone. Opaque specks are vegetal fragments,

5,6 . Sample $66-2,29-30 \mathrm{~cm}(\times 150)$ : Showing replacement of a radiolarian shell by a marketry of clinoptilolite crystals. Figure 6. Crossed polaroids.

Figures 7-9 Calcareous mudstones; middle part of the sequences. 7,8. Sample $63-1,65-68 \mathrm{~cm}(\times 100)$ : Calcareous mudstone, bearing planktonic foraminifers. On Figure 7 , middle left side, a large radiolarian. $\mathrm{CaCO}_{3}=40$ per cent, organic carbon $=0.55$ per cent.

9. Sample $62-3,7-10 \mathrm{~cm}(\times 150)$ : Calcareous mudstone with planktonic foraminifers. The central Hedbergella (or globigerinid?) contains clinoptilolite crystals in its chambers. On the lower right side, isolated clinoptilolite crystals. Small crystals with high relief are emeries. 
PLATE 1

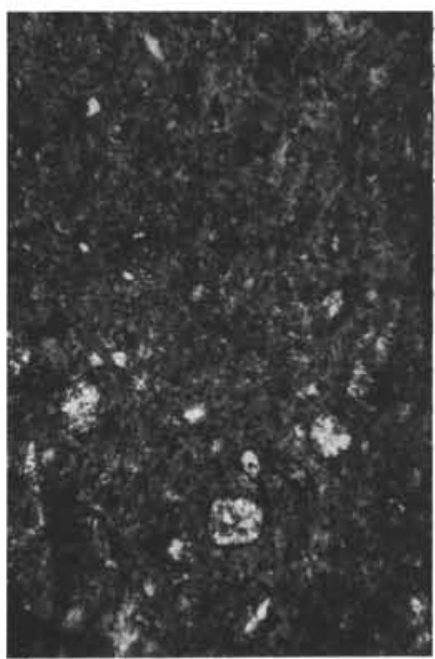

1

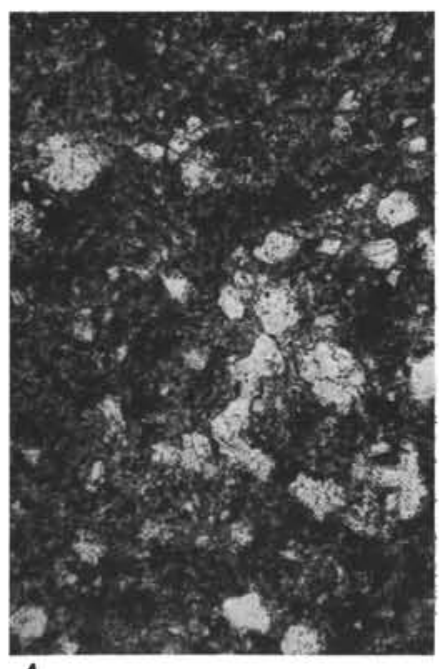

4

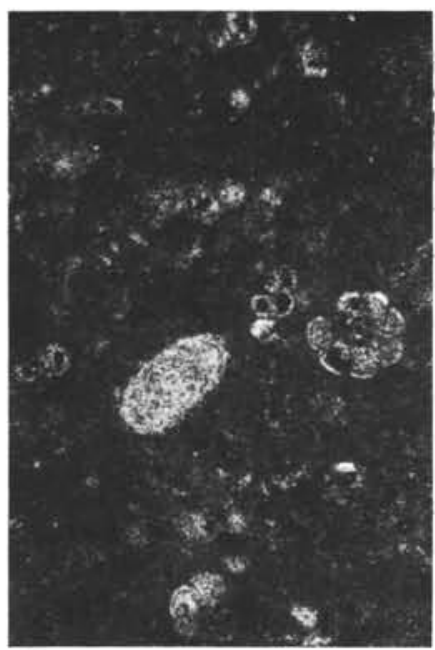

7
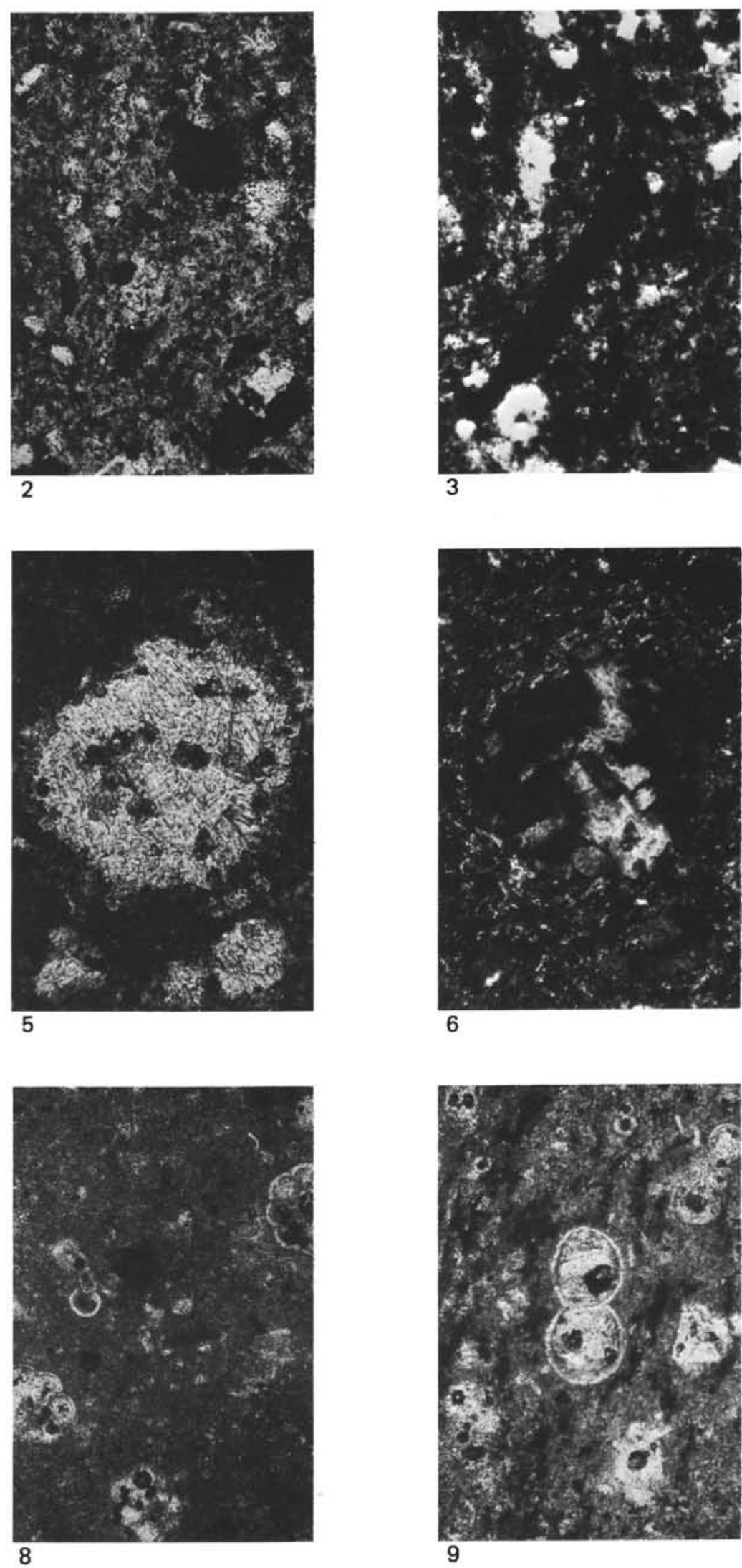
PLATE 2

Thin-Section Microphotographs, Hole 400A

Figures 1-3 Calcareous mudstones; middle part of the sequences.

1. Sample $64-1,74-76 \mathrm{~cm}(\times 100)$ : Microfossils within a calcareous mudstone. The Hedbergella contains a clinoptilolite crystal within one of its chambers. The apical part of the radiolarian is replaced by coarsely crystalline clinoptilolite; the other part is still siliceous. The matrix comprises both clay minerals and nannofossils.

2. Sample $63-1,65 \mathrm{~cm}(\times 100)$ : Siliceous radiolarian in a calcareous mudstone; scattered vegetal fragments; isolated clinoptilolite crystals; calcareous micritic matrix, mainly composed of nannofossils.

3. Sample $63-1,65-67 \mathrm{~cm}(\times 150)$ : Radiolarian shell infilled by clinoptilolite crystals.

Figures 4-6 Laminated silty claystone; uppermost part of a turbiditic sequence.

4. Sample $62-3,83-85 \mathrm{~cm}(\times 20)$ : Two-valved shell (pelecypod or brachiopod ?) in a laminated silty claystone. The shell is oriented roughly parallel to the lamination. White specks are clinoptilolites.

5,6. Sample $62-3,83-85 \mathrm{~cm}(\times 150)$ : Radiolarian shell within a laminated silty claystone. The radiolarian is completely siliceous. The skeleton is amorphous silica and is infilled with opal showing that silica has been displaced during an early stage of diagenesis previously to its replacement by zeolites. 5: parallel; 6: crossed polaroids.

Figures 7-9 Laminated silty claystone; between two slumped sequences.

7. Sample $64-2,96-97 \mathrm{~cm}(\times 20)$ : Low magnification of a laminated silty claystone. The laminations are underlined by clinoptilolite grains, argillaceous clusters, white mica flakes, and radiolarian shells. Matrix comprises mostly clays and calcareous nannofossils.

8. Sample $64-2$, $96-97 \mathrm{~cm}(\times 50)$ : Laminated silty claystone with planktonic foraminifers. The loge of this small Hedbergella is infilled with diagenetic pyrite. A large phosphatic grain in the upper middle. White grains: clinoptilolite.

9. Sample $64-2,96-97 \mathrm{~cm}(\times 150)$ : As in Figure 8 with higher magnification, clinoptilolite crystals. 
PLATE 2
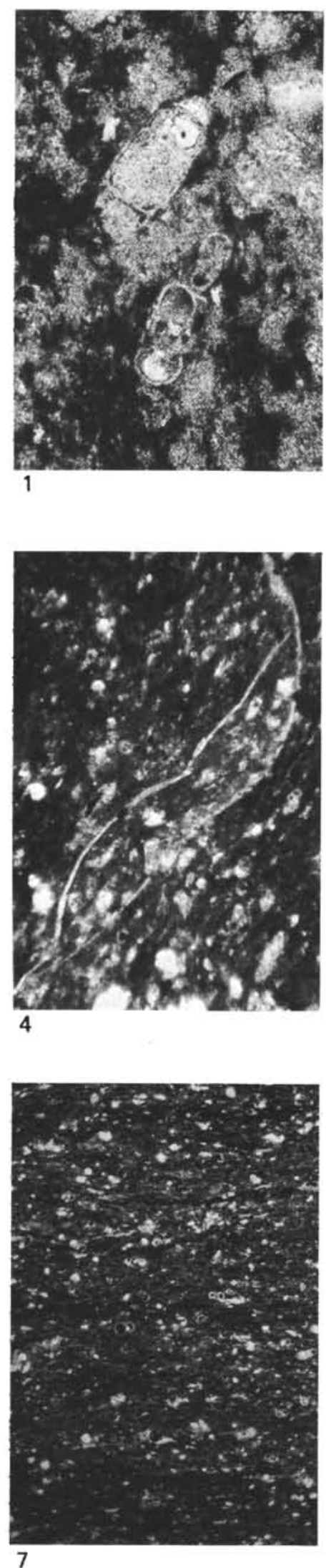
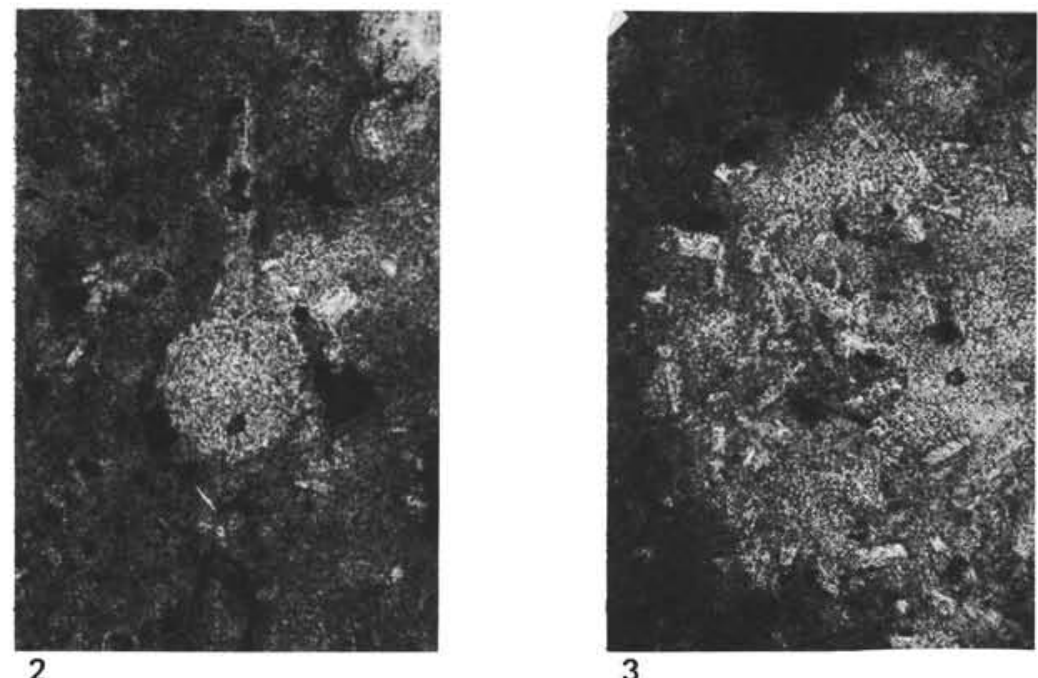

3
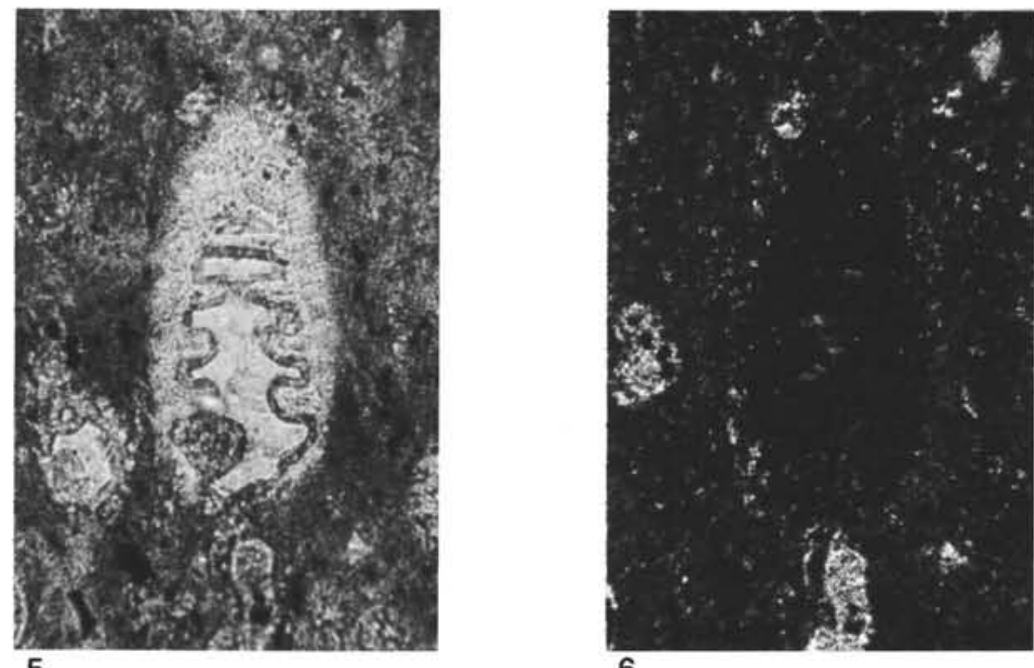

6
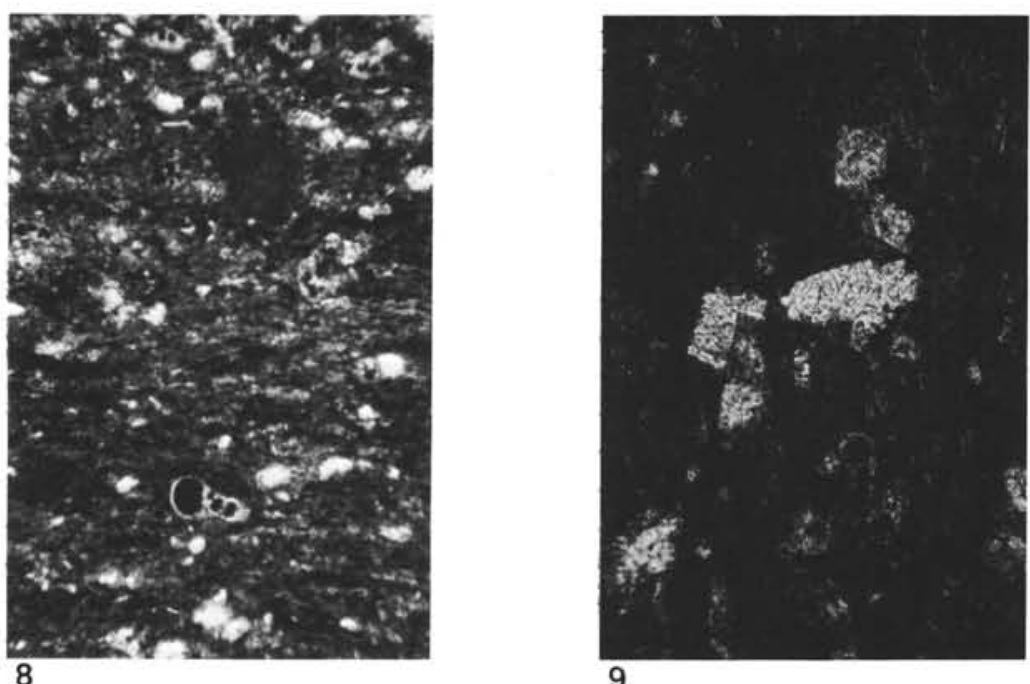
PLATE 3

Thin-Section Microphotographs, Hole 402A

Figures 1, 2 Sample 5-1, 25-30 $\mathrm{cm}(\times 25)$ : Crinoidal limestone, upper part of the Albian cycle. Dominating crinoid ossicles and urchin fragments associated with sponge spicules, benthic foraminifers, rare bryozoans, and a few quartz and glauconite grains (Vraconian).

Figure 3 Sample $18-4,60-63 \mathrm{~cm}(\times 25)$ : Graded sponge spicule-bearing limestone, middle part of the Albian cycle. Dominating micritic calcareous grains associated with sponge spicules, pelecypods (Inoceramus), holothurian sclerites, radiolarians replaced by clinoptilolite, and quartz grains. Benthic foraminifers, opaque minerals, phosphate grains, mica flakes, and vegetal debris are present. Conspicuous lamination in this part of graded sequence (middle Albian).

Figure $4 \quad$ Sample 21-1, 106-108 cm $(\times 100)$ : Micritic marly limestone, lower part of the Albian cycle. Abundant matrix with micritic calcite and clay minerals. Sparse radiolarians replaced by clinoptilolite, sponge spicules, Inoceramus prisms, holothurian sclerites and quartz, micas, and opaque minerals of small size. A benthic foraminifer in the middle of the view (lower Albian).

Figure 5 Sample 22-6, 120-124 cm $(\times 25)$ : Well-sorted bioclastic limestone; upper layers of the lower (mainly Gargasian) cycle. Dominating micritic grains and echinoderm fragments, sponge spicules, subordinate annelid tubes, benthic foraminifers, radiolarians, quartz grains, and mica flakes (lowermost Albian).

Figure $6 \quad$ Sample $25-3,45-48 \mathrm{~cm}(\times 25)$ : Wackestone with sparse radiolarians, foraminifers, vegetal fragments, opaque minerals; nannocones up to 10 to 20 per cent in the matrix. Radiolarians are generally replaced by clinoptilolite (lowermost Albian).

Figure 7 Sample $6-1,41-43 \mathrm{~cm}(\times 25)$ : Pithonellid-bearing micritic limestone; upper part of the Albian cycle. Pithonella sphaerica is the main component (up to $90 \%$ ) of the microfauna. Also Pithonella ovalis (rare), small urchin debris, rare Hedbergella (determination by Villain).

Figures 8, 9 Sample 6-1, 41-43 cm $(\times 100)$ : Details of view Figure 7. A section of Hedbergella in Figure 8 (Vraconian). 
PLATE 3

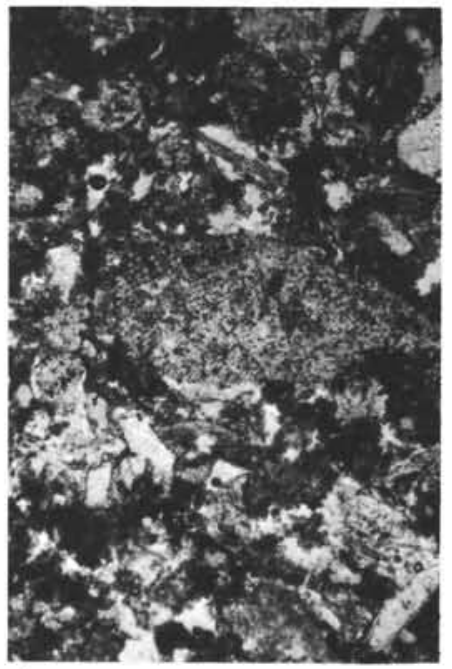

1
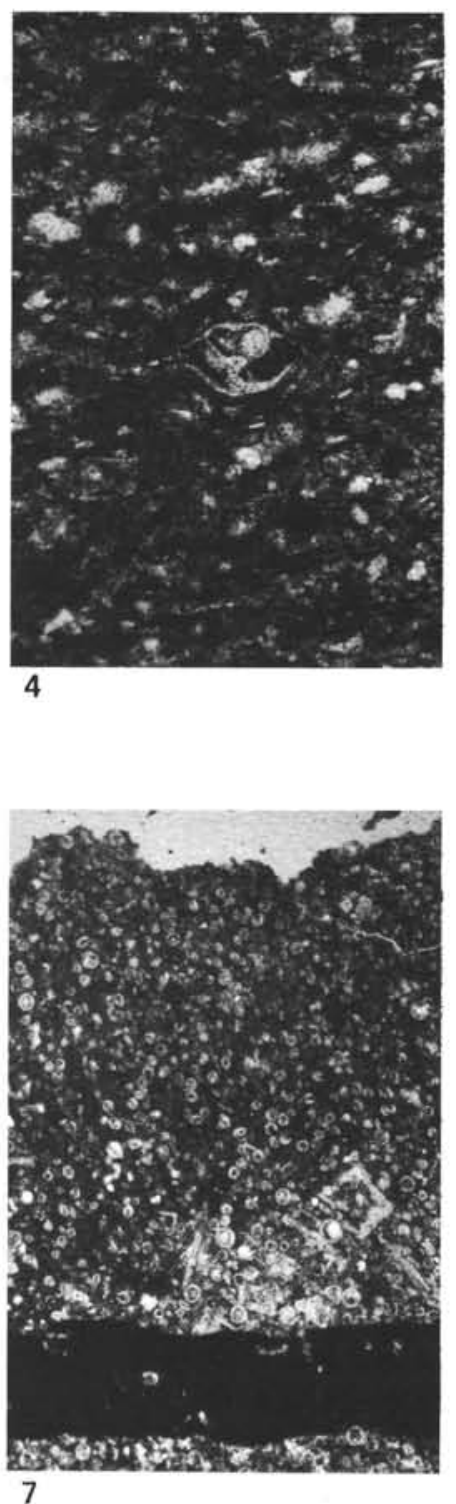
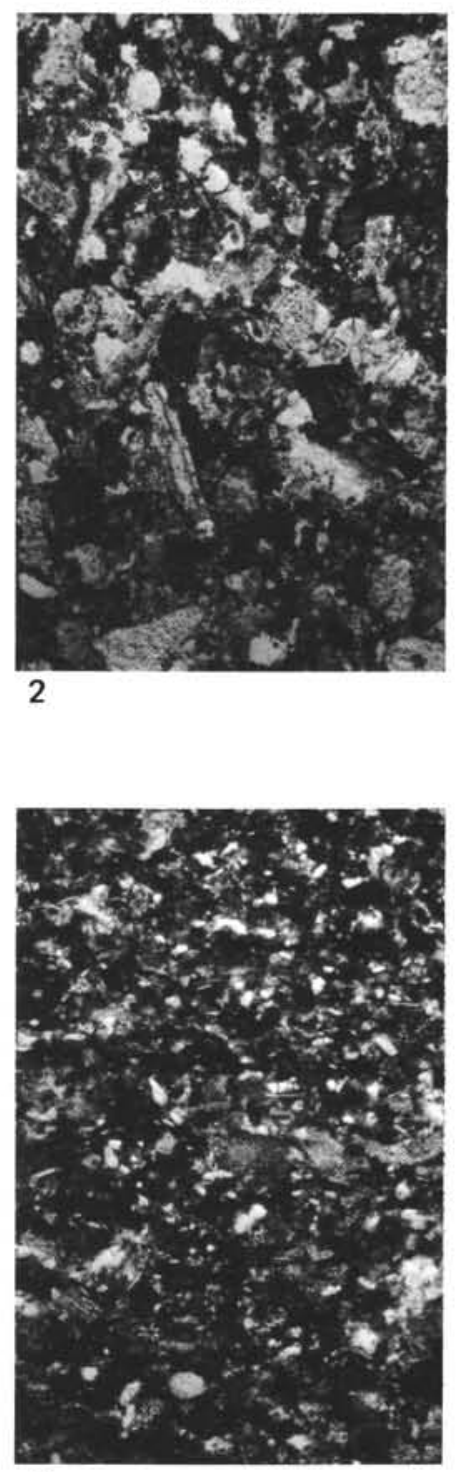

5

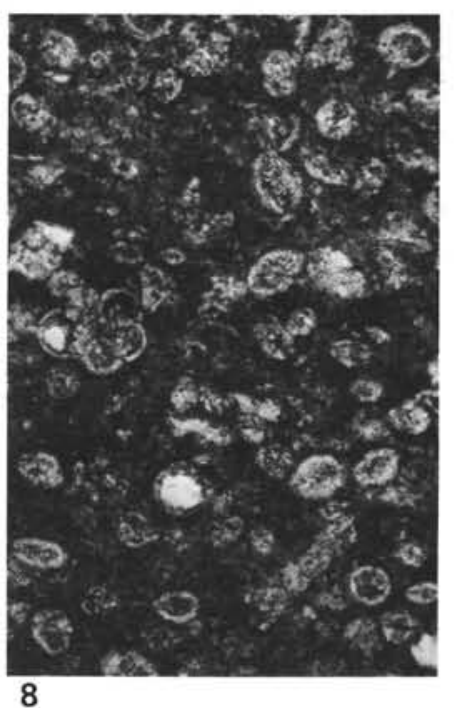

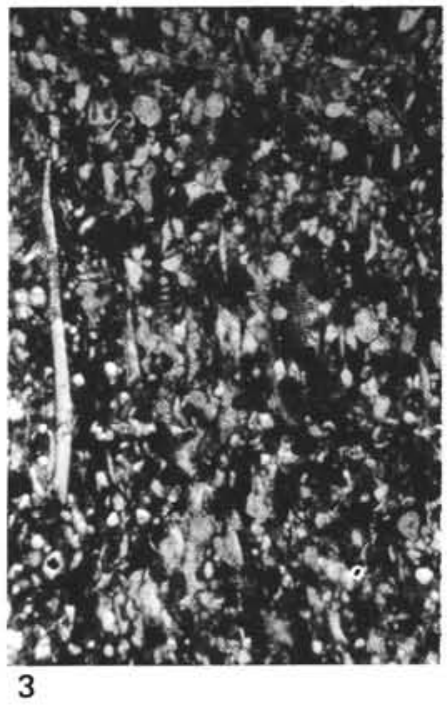
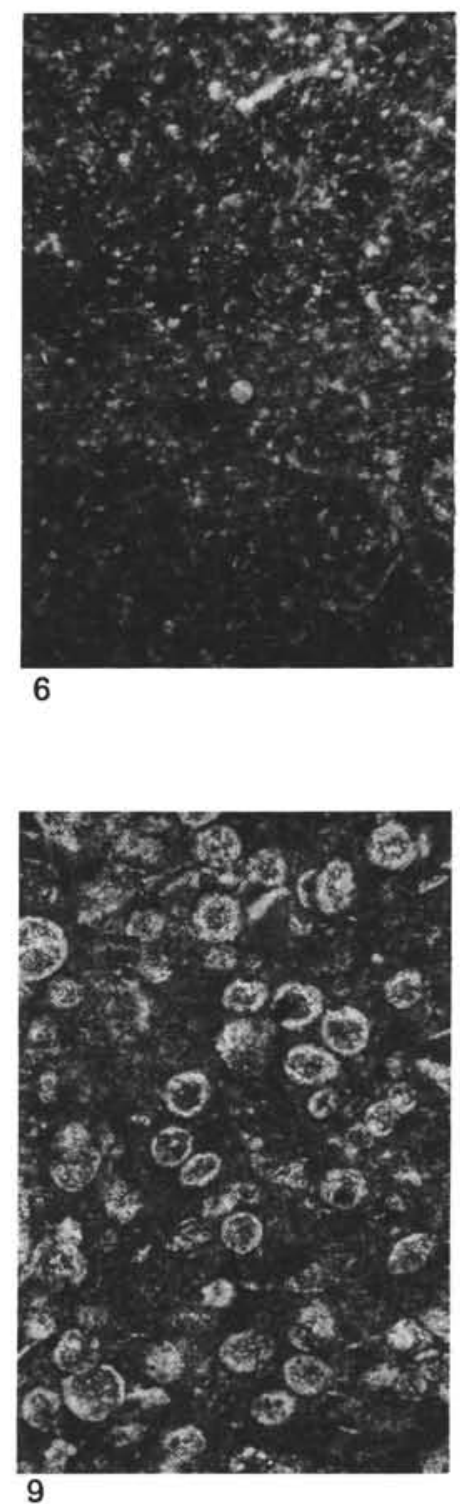
PLATE 4

Thin-Section Microphotographs, Hole 402A

Figures 1, 2 Sample $18-4,60-63 \mathrm{~cm}(\times 250)$ : Detail of double shell radiolarians (transverse) section in a laminated sponge spicule-bearing limestone; amorphous silica. In the same sample, some radiolarians are replaced by clinoptilolite (middle Albian).

Figure 3 Sample $18-4,60-63 \mathrm{~cm}(\times 250)$ : Tangential section of a radiolarian midphoto; mica flakes, annelid tube, a quartz grain, and calcite fragments (middle Albian).

Figure 4 Sample 21-1, 106-108 cm $(\times 250)$ : Transverse section of a double-shell radiolarian in a fine-grained graded bioclastic limestone (lower Albian).

Figure $5 \quad$ Sample $25-3,45-48 \mathrm{~cm}(\times 250)$ : Radiolarian replaced by clinoptilolite. Wackestone with sparse radiolarians, foraminifers, vegetal fragments, opaque minerals; nannoconids in the matrix (lowermost Albian).

Figure $6 \quad$ Sample $5-1,112-113 \mathrm{~cm}(\times 100)$ : Sponge spicule.

Figure 7 Sample 5-1, 112-113 cm $(\times 250)$ : Detail of sponge spicule in Figure 6. Sea orbicules in the amorphous silica; crinoidal limestone (Vraconian).

Figure $8 \quad$ Sample $32-6,150-152 \mathrm{~cm}(\times 25)$ : Burrow filled with replacement siderite. In the micritic matrix, sideritic rhombs are also scattered (lower Gargasian).

Figure 9 Sample 22-6, 12-14 cm $(\times 100)$ : Holothurian sclerite. Fine-grained bioclastic packstone, with micritic calcareous grains, echinoderm fragments, sponge spicules (lower Albian).

Figure 10 Sample $18-4,60-63 \mathrm{~cm}(\times 100)$ : Holothurian sclerite in a laminated sponge spicule-bearing limestone. Sponge spicules and micritic calcareous grains are the main components, with radiolarians, benthic foraminifers, and scarce mica flakes, quartz grains, glauconite, annelids (middle Albian).

Figure $11 \quad$ Sample $35-5,60-63 \mathrm{~cm}(\times 250)$ : Nannoconid-bearing micritic limestone (Bedoulian).

Figure 12 Sample $35-5,60-63 \mathrm{~cm}(\times 400)$ : Detail of the nannoconid-bearing limestone. 
PLATE 4

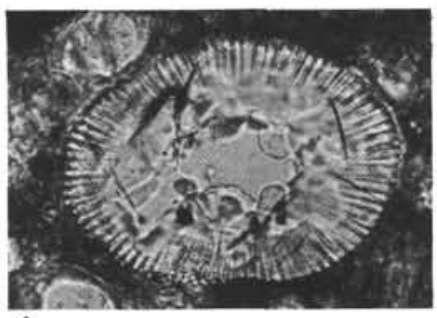

1

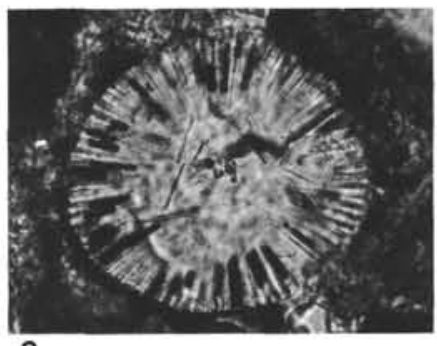

2

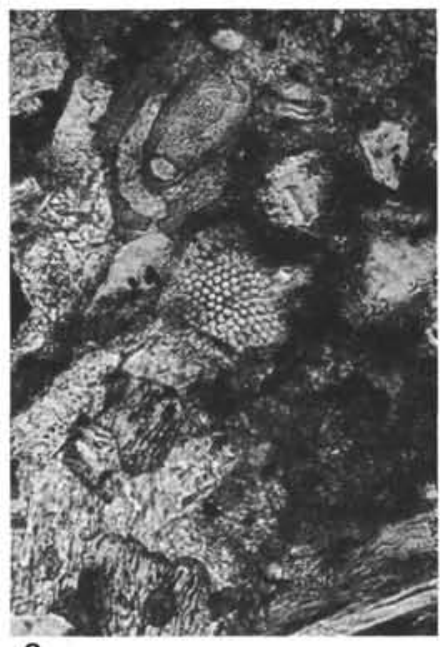

3

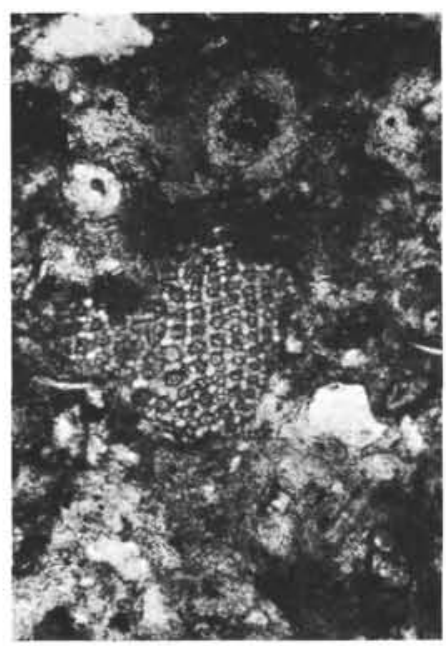

9
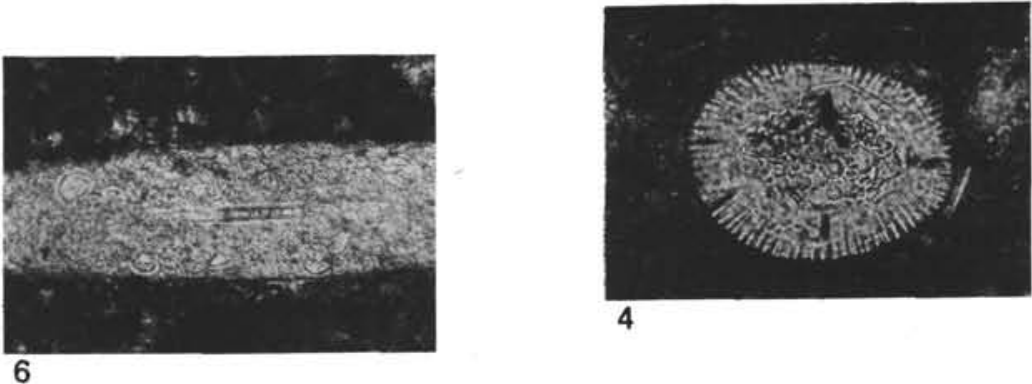

4
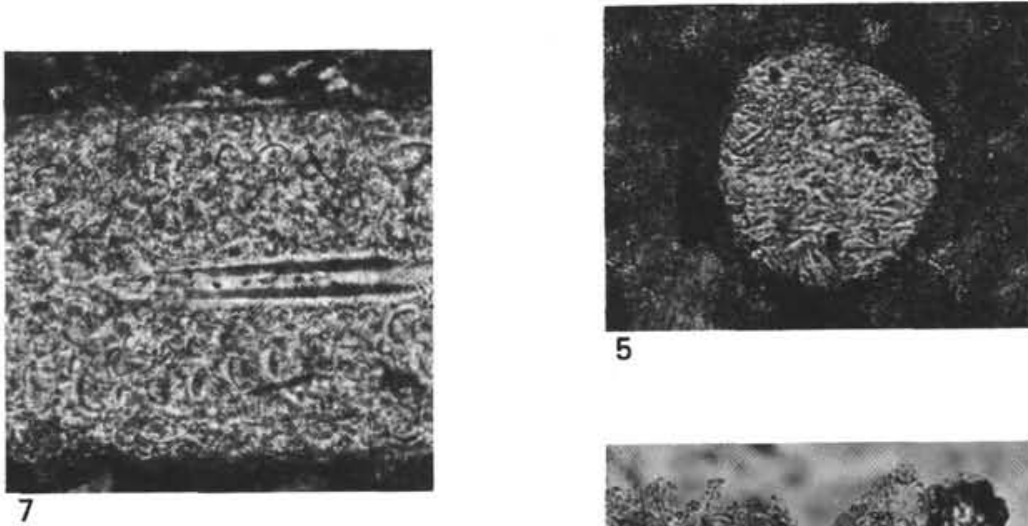

5

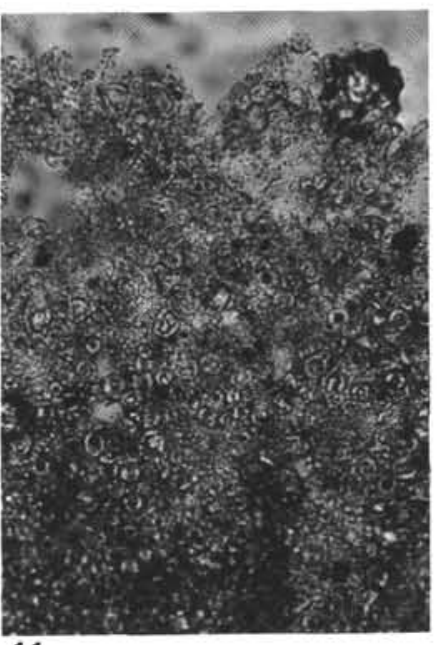

11

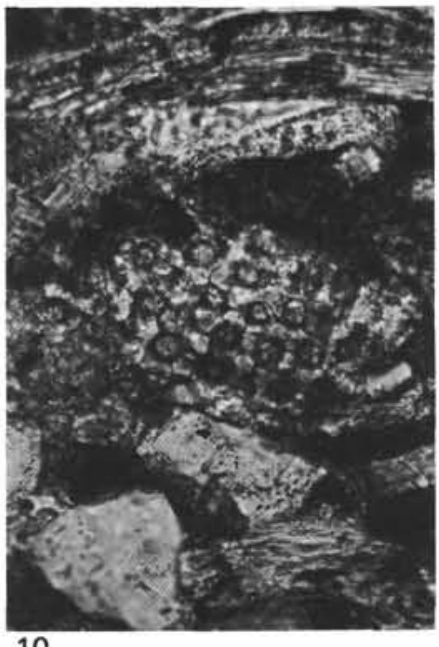

10

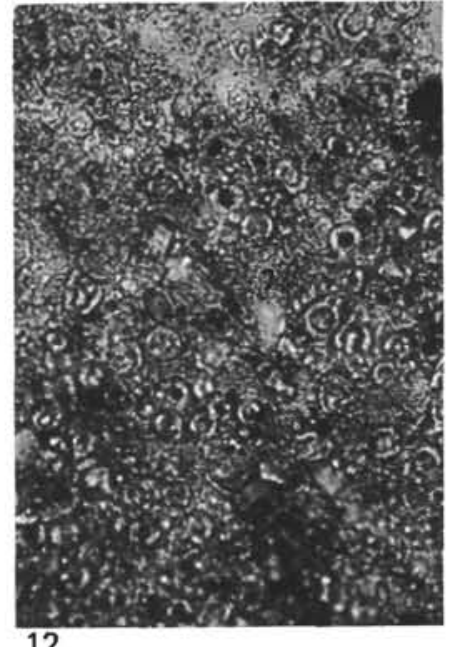

12 